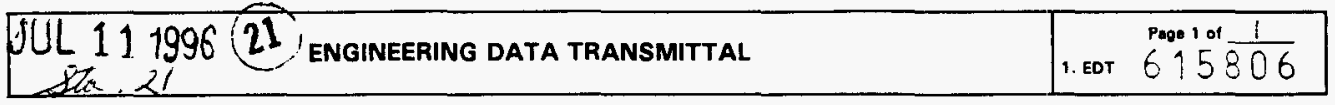

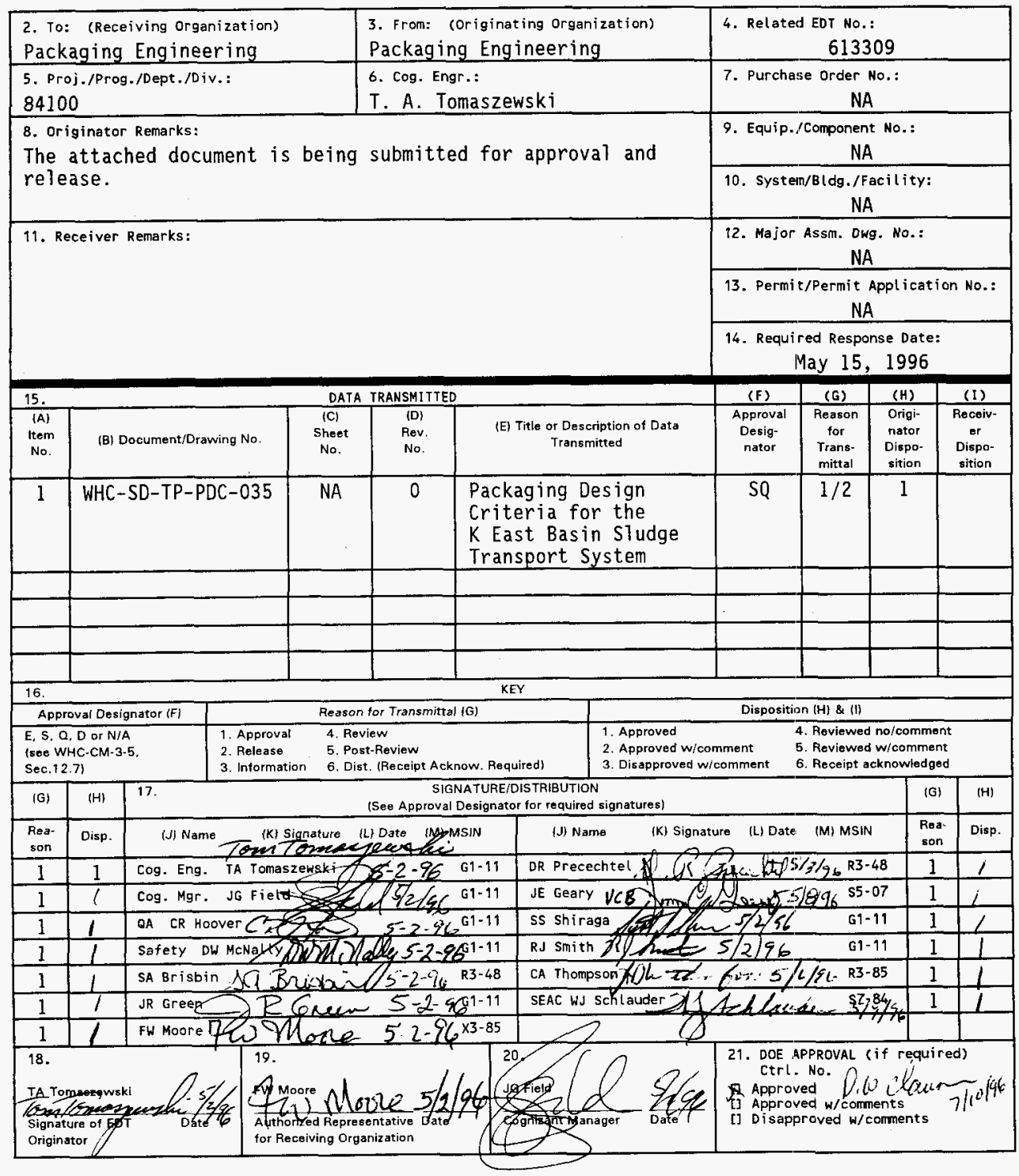

BD-7400-172-2 (04/94) GEF097 


\section{Packaging Design Criteria for the $K$ East Basin Sludge Transportation System}

T. A. Tomaszewski

Westinghouse Hanford Company, Richland, WA 99352

U.S. Department of Energy Contract DE-AC06-87RL10930
EDT/ECN: 615806
UC: 513
Org Code: 84100
Charge Code: LD124
B\&R Code: EW3135040 Total Pages: 52

Key Words: packaging, transport system, K East Basin, sludge, spent nuclear fuel (SNF)

Abstract: This packaging design criteria (PDC) establishes the onsite transportation safety criteria for a reusable packaging and transport system to transport $K$ East Basin sludge and water. This PDC provides the basis for the development of a safety analysis report for packaging; establishes the packaging contents and safety class of the package; and provides design criteria for the package, packaging, and transport systems.

TRADEMARK DISCLAIMER. Reference herein to any specific commercial product, process, or service by trade name, trademark, manufacturer, or otherwise, does not necessarily constitute or imply its endorsement, recommendation, or favoring by the United States Government or any agency thereof or its contractors or subcontractors.

Printed in the United States of America. To obtain copies of this document, contact: WHC/BCS

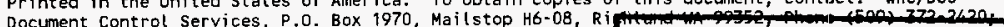
Fax (509) 376-4989.
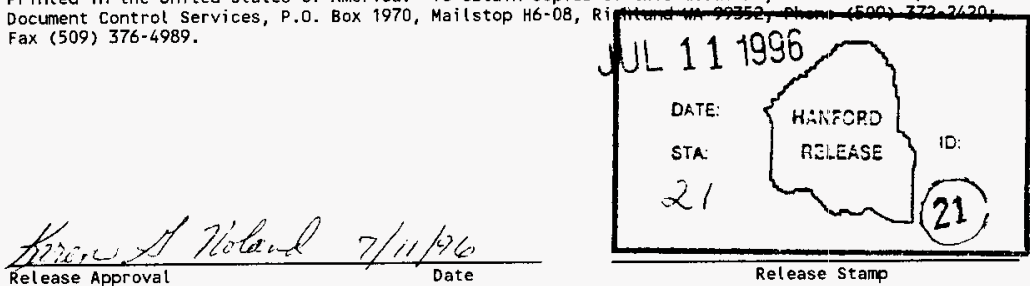

Release Stamp

Approved for Public Release 
1.0 INTRODUCTION . . . . . . . . . . . . . . . . . . . 1

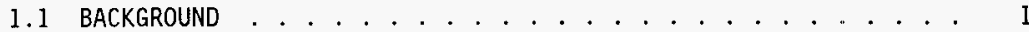

1.2 PURPOSE AND SCOPE ................. 1

1.3 JUSTIFICATION . . . . . . . . . . . . . . . . 1

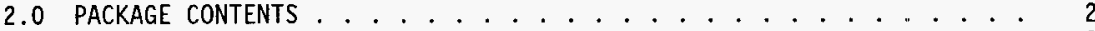

2.1 PAYLOAD DESCRIPTION .................. 2

2.2 RADIONUCLIDE COMPOSITION ................. 3

2.3 FISSILE CLASSIFICATION . . . . . . . . . . . . . . . 7

2.4 CHEMICAL COMPOSITION ....................... 11

2.5 TRANSPORTATION CLASS ........................... 12

2.6 THERMAL DESCRIPTION . . . . . . . . . . . . . . . . . 12

2.7 GAS GENERATION . . . . . . . . . . . . . . . 12

3.0 FACILITY OPERATIONS AND INTERFACES . . . . . . . . . . 12

3.1 ORIGINATING FACILITY . . . . . . . . . . . . . 12

3.2 RECEIVING FACILITY . . . . . . . . . . . . . 13

4.0 PACKAGING/TRANSPORT SYSTEM DESIGN CRITERIA . . . . . . . 13

4.1 GENERAL . . . . . . . . . . . . . . . . . . . . . . 13

4.2 PACKAGING AND CONTAINER . . . . . . . . . . . . . . . 14

4.2.1 General Requirements . . . . . . . . . . . . 14

4.2.2 Loading and Unloading .............. . . 15

4.2 .3 Material Requirements ............. 15

4.2 .4 Fabrication Methods . . . . . . . . . . . . . . 16

4.2.5 Dimensions and Volume . . . . . . . . . . . . . . 16

4.2 .6 Weight of Contents ............... 16

4.2.7 Maximum Gross Weight . . . . . . . . . . . . . . . . 16

4.2 .8 Shielding Requirements .............. 16

4.2.9 Ports, Seals, and Closures . . . . . . . . . . 17

4.2.10 Venting and Filters ............. 17

4.2.11 Heel Minimization and Removal ........... 17

4.2.12 Service Life . . . . . . . . . . . . . . . . . 17

4.2.13 Decontamination .............. . . 17

4.2.14 Tiedown and Lifting Attachments ........... 18

4.2.15 Containment Boundary . . . . . . . . . . . . . 18

4.3 TRANSPORT TRAILER . . . . . . . . . . . . . . . . . . . . . . . . . . . . . . 19

4.3.1 General Requirements . . . . . . . . . . . . . . 19

4.3.2 Regulatory Requirements ............ 19

4.3.3 Weight and Dimensional Requirements........ 20

4.3.4 Material and Structural Requirements . . . . . . . 20

4.3.5 Trailer Tiedown Structures............. 21

4.3.6 Landing Gear................. . . 21

4.3 .7 Suspension ................. 21

4.3 .8 Brake System . . . . . . . . . . . . 22

4.3 .9 King Pin................. . . . 22

4.3.10 Lighting ... . . . . . . . . . . . . 22

4.3.11 Painting . . . . . . . . . . . 22

4.3.12 Service Life and Additional Requirements . . . . . . . 23

4.4 SUPPORT EQUIPMENT . . . . . . . . . . . . . . 23 


\section{CONTENTS (cont)}

5.0 GENERAL REQUIREMENTS . . . . . . . . . . . . . . . . . . . . 24

5.1 TRANSPORTATION SAFETY . . . . . . . . . . . . . . . . . . . . . 24

5.1.1 Normal Conditions ................. . 24

5.1.2 Accident Conditions . . . . . . . . . . . . . . 25

5.1.3 Thermal .................... 26

5.1.4 Shielding . . . . . . . . . . . . . . . . 26

5.1.5 Criticality .................. 27

5.1.6 Environmental Data................ . 27

5.1.7 Gas Generation Analysis . . . . . . . . . . . 28

5.1.8 Containment . . . . . . . . . . . . . . . 29

5.2 ALARA . . . . . . . . . . . . . . . . . . . . . . 29

5.3 TRANSPORTATION SAFETY CLASS . . . . . . . . . . . . . . 29

5.4 MAINTENANCE, TOOLING, AND SPARES . . . . . . . . . . . . . . . 29

5.5 QUALITY ASSURANCE . . . . . . . . . . . . . . . . . . . . . 29

6.0 REFERENCES ......................... . . . . . 30

APPENDICES

A ORIGEN2 INPUT FILES FOR TOTAL SOURCE AND WORST SOURCE . . . . . . . . A-1

B TRANSPORTATION SAFETY CLASS ANALYSIS FOR SHIPMENT OF

SLUDGE FROM $K$ EAST BASIN . . . . . . . . . . . . . . . . . . . B-1

LIST OF TABLES

1 Physical Characteristics of K East Basin Sludge . . . . . . . . . . . 3

2 Uranium Isotopic Fractions . . . . . . . . . . . . . . . . . . . . 4

3 Mass and Activity, Total Sludge (May 1993) . . . . . . . . . . . . . 5

4 Mass and Activity, Water $(1994,1995)$. . . . . . . . . . . . . 6

5 Mass and Activity, Worst-Case Sludge (May 1993) . . . . . . . . . . . 8

6 Mass and Activity, Total Sludge and Water (May 1993) . . . . . . . . 9

7 Mass and Activity, Single Shipment, Worst Case (May 1993) . . . . . . 10

8 Chemical Constituents in K East Basin Sludge . . . . . . . . . . . . 11

9 0SD-T-151-00007 Limits . . . . . . . . . . . . . . . . . . 11

10 Packaging External Decontamination Limits . . . . . . . . . . . 18

11 Trailer Regulatory Standards . . . . . . . . . . . . . . . . 19

12 Trailer Characteristics... . . . . . . . . . . . . . 20

13 Peak Hanford Air Temperatures. . . . . . . . . . . . . . . . . . 28

14 Maximum Solar Radiation... . . . . . . . . . . . . . 28 
WHC-SD-TP-PDC-035 Rev. 0

\section{LIST OF TERMS}

AISC

ALARA

ASME

ASTM

BTU/h

CEDE

$\mathrm{Ci} / \mathrm{gal}$

$\mathrm{cm}$

container

DOT

$\mathrm{dpm} / \mathrm{cm}^{2}$

DST

FMVSS

$\mathrm{ft}^{3}$

$g$

gal

$\mathrm{g} / \mathrm{L}$

$\mathrm{g} / \mathrm{mL}$

HEPA

HRCQ

in.

$\mathrm{kg}$

$\mathrm{kg} / \mathrm{m}^{3}$

$\mathrm{km}$

$\mathrm{km} / \mathrm{h}$

$\mathrm{kPa}$

lb

$\mathrm{lb} / \mathrm{ft}^{3}$

$\mathrm{m}^{3}$

$\mu g / L$

$\mu \mathrm{m}$

$\mathrm{mi}$

$\mathrm{mi} / \mathrm{h}$

$\mathrm{mm}$

$\mathrm{mrem} / \mathrm{h}$

OSHA

package

packaging

payload

psi

NDA

NRC

PDC

PUREX

SAE

SARP
American Institute of Steel Construction

as low as reasonably achievable

American Society of Mechanical Engineers

American Society for Testing and Materials

British thermal units per hour

committed effective dose equivalent

curies per gallon

centimeter

The vesse 7 holding the sludge and water. Part of the packaging.

U.S. Department of Transportation

disintegrations per minute per cubic centimeter

double-shell tank

Federal Motor Vehicle Safety Standards

foot

cubic foot

gram

gallon

grams per liter

grams per milliliter

high-efficiency particulate air (filter)

highway route controlled quantity

inch

kilogram

kilograms per cubic meter

kilometer

kilometers per hour

kilopascal

pound

pounds per cubic foot

meter

cubic meter

micrograms per liter

micrometer (micron)

mile

miles per hour

millimeter

millirem per hour

Occupational Safety and Health Administration

The combination of packaging and payload.

The hardware that contains and protects the payload. Packaging includes the container.

The packaging contents. Sludge and water. pounds per square inch

nondestructive assay

U.S. Nuclear Regulatory Commission

packaging design criteria

Plutonium Uranium Reduction Extraction Facility

Society of Automotive Engineers

safety analysis report for packaging 
WHC-SD-TP-PDC-035 Rev. 0

\section{LIST OF TERMS (cont)}

SNF

TWRS

W

wt\% spent nuclear fuel

Tank Waste Remediation System watt

weight percent 
WHC-SD-TP-PDC-035 Rev. 0

\section{PACKAGING DESIGN CRITERIA FOR THE K EAST BASIN SLUDGE TRANSPORTATION SYSTEM}

\subsection{INTRODUCTION}

\subsection{BACKGROUND}

The K Basins, built in the early 1950s, provide underwater storage of N Reactor fuel irradiated from 1978 through 1987. In 1992, the decision to deactivate the Plutonium Uranium Reduction Extraction (PUREX) Facility precluded processing the approximately 2,100 metric tons (2,315 tons) of $\mathrm{N}$ Reactor spent nuclear fuel (SNF) left in the $\mathrm{K}$ Basins, where it has remained. A significant fraction of the SNF has become degraded due to cladding breaches during reactor discharge and corrosion has continued during storage.

The spent fuel is stored in open-top canisters, some of which have closed bottoms and others of which have screened bottoms. The open canisters release fission products into the basin water that, combined with environmental particulate matter, have settled to the bottom as sludge. Depths exceeding $0.9 \mathrm{~m}(3 \mathrm{ft})$ have been measured in some locations. Using sludge depth measurements, the total sludge volume in the $K$ East Basin is estimated to be as high as $67.5 \mathrm{~m}^{3}(17,832$ gal [Short 1995]).

The basin water and sludge have the potential to leak to the environment due to the age and condition of the Basin. Current planning is to remove the sludge, transport it to and place it into a selected Tank Waste Remediation System (TWRS) double-shel1 tank (DST) located in the 200 East Area. The particular tank has not yet been identified. This preferred sludge path forward alternative is identified in Alderman (1995).

\subsection{PURPOSE AND SCOPE}

This packaging design criteria (PDC) establishes the onsite transportation safety criteria for a reusable packaging and transport system to transport $K$ East Basin sludge and water. This PDC provides the basis for the development of a Safety Analysis Report for Packaging (SARP), establishes the packaging contents and safety class of the package, and provides design criteria for the package, packaging, and transport systems.

The SARP will approve the transport system for use on the Hanford Site and will demonstrate that the packaging meets the transportation safety requirements of WHC-CM-2-14, Hazardous Material Packaging and Shipping.

\subsection{JUSTIFICATION}

Various transport and packaging options were evaluated for transferring $K$ Basin sludge to the TWRS. The basis to use a trailer-mounted American Society of Mechanical Engineers (ASME) pressure vessel, approximately $3 \mathrm{~m}^{3}$ to 
$6 \mathrm{~m}^{3}$ (793 gal to 1,585 gal) in volume, is documented in Brisbin (1995b). An option from Brisbin (1995b) to use a high-integrity container was eliminated due to the activity level of the source term.

\subsection{PACKAGE CONTENTS}

The payload is expected to vary in size from a minimum of $3 \mathrm{~m}^{3}$ (793 gal) to a maximum of $6 \mathrm{~m}^{3}(1,585 \mathrm{gal})$, consisting of $20 \%$ to $30 \%$ sludge by volume, the rest being interstitial basin and process water. The sludge itself, in turn, consists of $17 \mathrm{wt} \%$ to $52 \mathrm{wt} \%$ of dry solids. It is the solids fraction that contributes the bulk of the radioactivity.

Sludge physical data are presented in Table 1; uranium isotopic fractions are shown in Table 2; mass and activity levels for the total sludge inventory, the water, the worst-case sludge, the total sludge and water, and the singleshipment worst case are presented in Tables 3 through 7.

Table data originate from Spent Nuclear Fuel Project Technical Databook (Short 1995) and represent best available data. Chemical and radionuclide data for the sludge and the radionuclide data for water are taken from Brisbin (1995a). The physical and radionuclide composition of the sludge is not distributed homogeneously throughout the basin; however, the inventory was averaged to more closely represent the expected removal process. All data were then adjusted to account for total volume, uranium isotopes, and other actinides, as discussed in Section 2.2 .

\subsection{PAYLOAD DESCRIPTION}

The payload is a mixture of basin water, process water, and sludge. The sludge is a radioactive mixture of solids and interstitial basin water (with dissolved solids). The sludge has a thin crust with underlying layers of solid and flocculent materials. The solids consist of fuel corrosion products; fuel pieces; uranium oxide and fission products; activated metals; concrete; grit; aluminum and iron oxides; paint; dirt, dust; and plant, insect, and previously airborne environmental debris. The basin water is radioactive and provides the covering to the sludge. The process water comes from the loading and flushing operations.

The wet sludge density, averaged over the entire K East Basin inventory, is $1,325 \mathrm{~kg} / \mathrm{m}^{3}$, with a range of 1,130 to $1,535 \mathrm{~kg} / \mathrm{m}^{3}$. The solid portion of the sludge varies from $17 \mathrm{wt} \%$ to $52 \mathrm{wt} \%$, the rest being interstitial basin water. After incorporating measurement uncertainties, the maximum total sludge volume is estimated to be $67.5 \mathrm{~m}^{3}$, with $50.51 \mathrm{~m}^{3}$ being the expected value.

Table 1 provides the physical characteristics of the K East Basin sludge. 
WHC-SD-TP-PDC-035 Rev. 0

Table 1. Physical Characteristics of K East Basin Sludge.

\begin{tabular}{|c|c|}
\hline Property & Range \\
\hline Density ${ }^{1}$ & $1.13-1.535 \mathrm{~g} / \mathrm{mL}$ \\
\hline Mean particle size 2 & $1.53-1.68 \mathrm{\mu m}$ \\
\hline Solids $(w t \%)^{3}$ & $17.52 \%-51.29 \%$ \\
\hline Sludge volume & $\begin{array}{l}67.5 \mathrm{~m}^{3} \text { maximum } \\
50.51 \mathrm{~m}^{3} \text { average }\end{array}$ \\
\hline
\end{tabular}

\subsection{RADIONUCLIDE COMPOSITION}

The $K$ East Basin contains irradiated fuel that is stored underwater. Along with this irradiated fuel is a buildup of sludge that has settled to the bottom of the basin. When the sludge is removed from the basin, it will be mixed in with the water from the basin, which is contaminated at a negligible level. It is assumed the waste will consist of $30 \%$ sludge and $70 \%$ water by volume (from a maximum expected "sludge pumping efficiency" of $30 \%$ ).

This section characterizes two source terms. The first source represents the total source inventory to be shipped. This source consists of $67.5 \mathrm{~m}^{3}$ of sludge and $157.4 \mathrm{~m}^{3}$ of water for a total volume of $224.9 \mathrm{~m}^{3}$. The second source represents the worst-case source expected for a single shipment and consists of $1.8 \mathrm{~m}^{3}$ of sludge and $4.2 \mathrm{~m}^{3}$ of water for a total volume of $6.0 \mathrm{~m}^{3}$.

The curie inventories for the K East Basin were decayed to Nay 1993 (Short 1995). The radionuclide inventories from Short (1995) did not include an isotopic breakdown of the uranium isotopes, but did include the total amount of uranium present. To determine the isotopic breakdown of the uranium, it was assumed the concentrations would be similar to that for Mark $1 \mathrm{~A}$ fuel with an approximate burnup resulting in $12 \%{ }^{240} \mathrm{Pu}$ (Schwarz 1992). Mark IA fuel was used, because it contains more highly enriched uranium than Mark IV fuel; $12 \%{ }^{240} \mathrm{Pu}$ was used, because it is similar to the plutonium mixture specified for the sludge.

Table 2 lists the estimated isotopic uranium concentrations for the total source, the water, and the worst-case sludge source terms. The uranium mass present in the sludge for the total sludge source and the worst-case sludge source is provided in short (1995). The isotopic breakdown of this total mass was calculated by taking the total mass and multiplying by the mass fractions for each isotope. The water does not include a uranium mass. To estimate the amount of uranium in the water, the sludge uranium mass was multiplied by the amount of plutonium in the water divided by the amount of plutonium in the sludge. 
Table 2. Uranium Isotopic Fractions.

\begin{tabular}{|c|c|c|c|c|}
\hline Isotope & Fraction ${ }^{1}$ & $\begin{array}{l}\text { S7udge mass } \\
\text { for } 50.51 \mathrm{~m}^{3} \\
(\mathrm{~g})\end{array}$ & Water $(\mu \mathrm{g} / \mathrm{L})$ & $\begin{array}{l}\text { Worst sludge } \\
\text { mass for } \\
1.37 \mathrm{~m}^{3} \quad(g) \\
\end{array}$ \\
\hline${ }^{234} \mathrm{U}$ & $7.16 \mathrm{E}-05$ & $1.05 \mathrm{E}+02$ & $1.98 \mathrm{E}-02$ & $5.79 E+00$ \\
\hline${ }^{235} \mathrm{U}$ & $8.45 E-03$ & $1.23 E+04$ & $2.34 E+00$ & $6.83 E+02$ \\
\hline $236 \mathrm{U}$ & $1.02 \mathrm{E}-03$ & $1.49 \mathrm{E}+03$ & $2.83 \mathrm{E}-01$ & 8.27E+01 \\
\hline${ }^{238} \mathrm{U}$ & $9.90 \mathrm{E}-01$ & $1.45 E+06$ & $2.74 E+02$ & $8.00 E+04$ \\
\hline Tota 7 & $1.00 E+00$ & $1.46 \mathrm{E}+06^{2}$ & $2.76 \mathrm{E}+02^{3}$ & $8.08 E+04^{2}$ \\
\hline
\end{tabular}

Table 3 lists the mass and activity for all of the sludge to be shipped, decayed to May 1993. For the SARP, these values should be decayed to the latest expected shipping date to account for the buildup of $241 \mathrm{Am}$. The values for a volume of $50.51 \mathrm{~m}^{3}$ were obtained from Short (1995). Uncertainties in the sludge mass could result in a total sludge volume of 67.5 $\mathrm{m}^{3}$ being shipped. To be conservative, the values in Table 3 were then multiplied by a factor of $67.5 / 50.51=1.336$ to determine an upper limit mass and activity for $67.5 \mathrm{~m}^{3}$, which is also listed in Table 3 .

Notice that according to Table 3 , that $12.9 \%(628 / 4,880)$ of the plutonium is ${ }^{240} \mathrm{Pu}$. Also notice that the uranium masses calculated in Table 2 for a volume of $50.51 \mathrm{~m}^{3}$ are included in this table.

By comparing measurement values with calculated values, a number of radionuclides are calculated to exist, but have not been accounted for in the measurement data. Some of the more important isotopes are ${ }^{244} \mathrm{~cm}$, which dominates the neutron source; ${ }^{208} \mathrm{Tl}$ and ${ }^{212} \mathrm{Bi}$, which are decay products ${ }^{\circ 2}{ }^{236} \mathrm{Pu}$ and contribute to the high-energy gamma-ray source; and ${ }^{144} \mathrm{Pr},{ }^{105} \mathrm{Rh},{ }^{125} \mathrm{Sb}$, and ${ }^{34} \mathrm{C} s$, which also make major contributions to the gamma-ray source term.

These isotopes are not accounted for in this analysis and further work should be done for the SARP to determine if any of these isotopes are present in the sludge.

Table 4 lists the mass and activity of the water provided in Brisbin (1995a) from measurements made in 1994 and 1995 . The numbers are in units of $\mu \mathrm{Ci} / \mathrm{L}$. These numbers were used to determine the mass and activity in $157.4 \mathrm{~m}^{3}$ of water and $4.2 \mathrm{~m}^{3}$ of water. Given that there is a total of $67.5 \mathrm{~m}^{3}$ of sludge, which will make up $30 \%$ of the source, then there must be $157.4 \mathrm{~m}^{3}$ of water included with the sludge to make up the other $70 \%$ of the source. sjmilarly, each shipment will contain $6 \mathrm{~m}^{3}$ of waste, which corresponds to 1.8 $\mathrm{m}^{3}$ of sludge and $4.2 \mathrm{~m}^{3}$ of water. 
Table 3. Mass and Activity, Total Sludge (May 1993).

\begin{tabular}{|c|c|c|c|c|}
\hline \multirow{2}{*}{ Isotope } & \multicolumn{2}{|c|}{ Volume $\left(50.51 \mathrm{~m}^{3}\right)^{1}$} & \multicolumn{2}{|c|}{ Volume $\left(67.5 \mathrm{~m}^{3}\right)^{2}$} \\
\hline & $\mathrm{Ci}^{3}$ & Grams & $\mathrm{Ci}$ & Grams \\
\hline${ }^{60} \mathrm{Co}$ & $2.86 \mathrm{E}+01$ & $2.53 \mathrm{E}-02$ & $3.82 E+01$ & $3.38 \mathrm{E}-102$ \\
\hline${ }^{90} \mathrm{Sr}$ & $1.33 E+03$ & $9.75 E+00$ & $1.78 \mathrm{E}+03$ & $1.30 \mathrm{E}+01$ \\
\hline${ }^{90} \mathrm{Y}$ & $1.33 E+03$ & $2.44 \mathrm{E}-03$ & $1.78 \mathrm{E}+03$ & $3.26 \mathrm{E}-03$ \\
\hline${ }^{137} \mathrm{Cs}$ & $1.01 E+03$ & $1.16 E+01$ & $1.35 E+03$ & $1.55 \mathrm{E}+01$ \\
\hline${ }^{137 m} \mathrm{Ba}$ & $9.55 \mathrm{E}+02$ & $1.78 \mathrm{E}-06$ & $1.28 E+03$ & $2.37 \mathrm{E}-06$ \\
\hline${ }^{154} \mathrm{Eu}$ & $2.98 \mathrm{E}+01$ & $1.10 \mathrm{E}-01$ & $3.98 E+01$ & $1.47 \mathrm{E}-01$ \\
\hline${ }^{155} \mathrm{Eu}$ & $1.70 \mathrm{E}+01$ & $3.66 \mathrm{E}-02$ & $2.27 \mathrm{E}+01$ & $4.88 E-02$ \\
\hline${ }^{238} \mathrm{Pu}$ & $6.60 \mathrm{E}+01$ & $3.86 \mathrm{E}+00$ & $8.81 E+01$ & $5.15 E+00$ \\
\hline${ }^{239} \mathrm{Pu}$ & $2.60 \mathrm{E}+02$ & $4.18 E+03$ & $3.47 \mathrm{E}+02$ & $5.59 E+03$ \\
\hline${ }^{240} \mathrm{Pu}$ & $1.43 \mathrm{E}+02$ & $6.28 \mathrm{E}+02$ & $1.91 \mathrm{E}+02$ & $8.38 E+102$ \\
\hline${ }^{241} \mathrm{Pu}$ & $5.66 \mathrm{E}+03$ & $5.49 E+01$ & $7.56 \mathrm{E}+03$ & $7.34 E+10]$ \\
\hline${ }^{242} \mathrm{Pu}$ & $4.36 \mathrm{E}-02$ & $1.14 \mathrm{E}+01$ & $5.82 \mathrm{E}-02$ & $1.52 E+101$ \\
\hline${ }^{241} \mathrm{Am}$ & $7.69 \mathrm{E}+02$ & $2.24 \mathrm{E}+02$ & $1.03 E+03$ & $2.99 \mathrm{E}+102$ \\
\hline${ }^{234} \mathrm{U}$ & $6.53 \mathrm{E}-01$ & $1.05 \mathrm{E}+02^{4}$ & $8.72 \mathrm{E}-01$ & $1.40 \mathrm{E}+102$ \\
\hline${ }^{235} \mathrm{U}$ & $2.67 \mathrm{E}-02$ & $1.23 \mathrm{E}+04^{4}$ & $3.56 \mathrm{E}-02$ & $1.65 \mathrm{E}+04$ \\
\hline${ }^{236} \mathrm{U}$ & $9.67 \mathrm{E}-02$ & $1.49 \mathrm{E}+03^{4}$ & $1.29 \mathrm{E}-01$ & $2.00 \mathrm{E}+103$ \\
\hline${ }^{238} \mathrm{U}$ & $4.86 \mathrm{E}-01$ & $1.45 \mathrm{E}+06^{4}$ & $6.49 \mathrm{E}-01$ & $1.93 \mathrm{E}+06$ \\
\hline Total & $1.16 \mathrm{E}+04$ & $1.47 \mathrm{E}+06$ & $1.55 E+04$ & $1.96 \mathrm{E}+06$ \\
\hline
\end{tabular}

'Source: Short, s. M., 1995, Spent Nuclear Fuel Project Technical Databook, WHC-SD-SNF-TI-015, ReV. 0, Westinghouse Hanford Company, Richland, Washington (Table 2.4).

2 Table 2.1 from short (1995).

3 Table 3.11 from short (1995).

${ }^{4}$ values from Table 2 . 
WHC-SD-TP-PDC-035 Rev. 0

Table 4. Mass and Activity, Water (1994, 1995).

\begin{tabular}{|c|c|c|c|c|c|c|}
\hline \multirow{2}{*}{ Isotope } & \multirow{2}{*}{$\mu \mathrm{Ci} / \mathrm{L}^{1}$} & \multirow{2}{*}{$\mu \mathrm{g} / \mathrm{L}$} & \multicolumn{2}{|c|}{$\begin{array}{c}\text { Total inventory for } \\
157.4 \mathrm{~m}^{3}\end{array}$} & \multicolumn{2}{|c|}{ Inventory for $4.2 \mathrm{~m}^{3}$} \\
\hline & & & $\mathrm{Ci}$ & Grams & $\mathrm{Ci}$ & Grams \\
\hline${ }^{3} \mathrm{H}$ & $1.52 \mathrm{E}-03$ & $1.58 \mathrm{E}-07$ & $2.39 \mathrm{E}-04$ & $2.48 \mathrm{E}-08$ & $6.38 \mathrm{E}-06$ & $6.62 E-10$ \\
\hline${ }^{90} \mathrm{Sr}$ & $8.30 E+00$ & $6.09 \mathrm{E}-02$ & $1.31 \mathrm{E}+00$ & $9.58 \mathrm{E}-03$ & $3.49 \mathrm{E}-02$ & $2.56 \mathrm{E}-04$ \\
\hline${ }^{90} \mathrm{Y}^{2}$ & $8.30 E+00$ & $1.53 \mathrm{E}-05$ & $1.31 E+00$ & $2.40 \mathrm{E}-06$ & $3.49 \mathrm{E}-02$ & $6.41 E-08$ \\
\hline${ }^{137} \mathrm{Cs}$ & $1.30 \mathrm{E}+01$ & $1.49 \mathrm{E}-01$ & $2.05 E+00$ & $2.35 \mathrm{E}-02$ & $5.46 \mathrm{E}-02$ & $6.28 \mathrm{E}-04$ \\
\hline${ }^{137} \mathrm{Ba}^{3}$ & $1.30 \mathrm{E}+01$ & $2.42 \mathrm{E}-08$ & $2.05 \mathrm{E}+00$ & $3.80 \mathrm{E}-09$ & $5.46 \mathrm{E}-02$ & $1.02 \mathrm{E}-10$ \\
\hline${ }^{238} \mathrm{Pu}$ & $9.95 \mathrm{E}-03$ & $5.81 \mathrm{E}-04$ & $1.57 \mathrm{E}-03$ & $9.15 \mathrm{E}-05$ & $4.18 \mathrm{E}-05$ & $2.44 \mathrm{E}-05$ \\
\hline${ }^{239} \mathrm{Pu}^{4}$ & $4.51 \mathrm{E}-02$ & $7.26 \mathrm{E}-01$ & $7.10 \mathrm{E}-03$ & $1.14 \mathrm{E}-01$ & $1.89 \mathrm{E}-04$ & $3.05 \mathrm{E}-03$ \\
\hline${ }^{240} \mathrm{Pu}^{4}$ & $4.51 \mathrm{E}-02$ & $1.98 \mathrm{E}-01$ & $7.10 \mathrm{E}-03$ & $3.12 \mathrm{E}-02$ & $1.89 \mathrm{E}-04$ & $8.31 \mathrm{E}-04$ \\
\hline${ }^{241} \mathrm{Am}$ & $2.07 E-01$ & $6.03 \mathrm{E}-02$ & $3.26 \mathrm{E}-02$ & $9.49 \mathrm{E}-03$ & $8.69 \mathrm{E}-04$ & $2.53 \mathrm{E}-04$ \\
\hline $234 \mathrm{U}$ & $1.24 \mathrm{E}-04$ & $1.98 \mathrm{E}-02^{5}$ & $1.95 \mathrm{E}-05$ & $3.12 \mathrm{E}-03$ & $5.19 \mathrm{E}-07$ & $8.31 \mathrm{E}-05$ \\
\hline${ }^{235} \mathrm{U}$ & $5.05 \mathrm{E}-06$ & $2.34 \mathrm{E}+00^{5}$ & $7.95 \mathrm{E}-07$ & $3.68 \mathrm{E}-01$ & $2.12 \mathrm{E}-08$ & $9.81 \mathrm{E}-03$ \\
\hline${ }^{236} \mathrm{U}$ & $1.83 \mathrm{E}-05$ & $2.83 \mathrm{E}-01^{5}$ & $2.88 \mathrm{E}-06$ & $4.45 \mathrm{E}-02$ & $7.69 \mathrm{E}-08$ & 1. $19 \mathrm{E}-03$ \\
\hline${ }^{238} \mathrm{U}$ & $9.20 \mathrm{E}-05$ & $2.74 \mathrm{E}+02^{5}$ & $1.45 \mathrm{E}-05$ & $4.31 E+01$ & $3.87 \mathrm{E}-07$ & $1.15 \mathrm{E}+00$ \\
\hline Total & $4.29 E+01$ & $2.78 \mathrm{E}+02$ & $6.75 \mathrm{E}+00$ & $4.37 E+01$ & $1.80 E-01$ & $1.17 \mathrm{E}+00$ \\
\hline
\end{tabular}

'source: Brisbin, S. A., 1995, Data for Preparation of the K Bas in Sludge Packaging Design Criteria (internal mena SAB-95-007 to $T$. A. Tomaszewski, December 8), Westinghouse Hanford Company, Richland, Washington.

${ }^{2}$ Assumed equal to ${ }^{90} \mathrm{Y}$.

${ }^{3}$ Content assumed equal to 137 Cs.

$4239 \mathrm{Pu}$ and ${ }^{240} \mathrm{Pu}$ assumed equal to total because breakdown not provided.

5 values obtained from Table 2 . 
Table 5 lists the mass and activity of the area in the K East Basin with the highest radioactivity per volume. The worst case exists for the wash pit, which has a volume of $1.37 \mathrm{~m}^{3}$. Values from Short (1995) were scaled to determine the mass and activity for a $1.8-\mathrm{m}^{3}$ sludge source. (In actuality, the wash pit data were derived from the weasel pit data; therefore, in effect, they are equally worst-case.)

Table 6 combines the sludge information from Table 3 and the water information from Table 4 to show the total mass and activity of the waste to be shipped.

Table 7 combines the water information from Table 4 and the worst-case sludge information from Table 5 to show the worst-case source in a single $6-\mathrm{m}^{3}$ payload.

For the values in Tables 6 and 7, an Origen 2 run was made to determine if all of the major isotopes had been included. Some minor act inides were added to the list, because they contribute to the actinide photon source. These actinides were decayed ten years to approximate the minimum decay time since the reactor was shut down.

Appendix A contains the Origen2 input files used to calculate the additional actinides included in Tables 6 and 7 . In addition, it contains the peer review checklist used during development of the K East Basin sludge container source term.

\subsection{FISSILE CLASSIFICATION}

The payload is classified as "fissile material" per WHC-CM-2-14.

Known fissile isotopes present in the sludge are ${ }^{235} \mathrm{U},{ }^{238} \mathrm{Pu},{ }^{239} \mathrm{Pu}$, and ${ }^{241} \mathrm{Pu}$ (see Tables). The fissile content of the water (Table 4) is negligible.

A $1.8 \mathrm{~m}^{3}$ payload of "average sludge" (Tables 3,4 , and 6) contains $591 \mathrm{~g}$ of fissile material. (The total sludge fissile inventory $(22.17 \mathrm{~kg}$ ) from Table 6 , multiplied by the maximum anticipated sludge shipment size $\left(1.8 \mathrm{~m}^{3}\right)$, ratioed by the total sludge inventory $\left(67.5 \mathrm{~m}^{3}\right)$, equals an "average sludge" shipment fissile content of $591 \mathrm{~g}\left(22,168 \mathrm{~g} \times 1.8 \mathrm{~m}^{3} / 67.5=59 \mathrm{~g}\right)$.

A $1.8 \mathrm{~m}^{3}$ payload of "worst case sludge" (Tables 5 and 7) contains 1,218 $\mathrm{g}$ of fissile material. (The "worst case" single-shipment sludge fissile inventory $[1,218 \mathrm{~g}]$ is summed directly from Table 7.)

The transportation index will be determined in the SARP based on a criticality analysis using the criteria of Section 5.1.5. Sludge transfers shall be controlled within the limits specified by the SARP. 
WHC-SD-TP-PDC-035 Rev. 0

Table 5. Mass and Activity, Worst-Case Sludge (May 1993).

\begin{tabular}{|c|c|c|c|c|}
\hline \multirow{2}{*}{ Isotope } & \multicolumn{2}{|c|}{ Inventory for $1.37 \mathrm{~m}^{3}$} & \multicolumn{2}{|c|}{ Inventory for $1.8 \mathrm{~m}^{3}$} \\
\hline & $\mathrm{Ci} \mathrm{i}^{1}$ & Grams & $\mathrm{Ci}$ & Grams \\
\hline${ }^{60} \mathrm{Co}$ & $1.28 \mathrm{E}+00$ & $1.13 \mathrm{E}-03$ & $1.68 \mathrm{E}+00$ & $1.49 \mathrm{E}-03$ \\
\hline${ }^{90} \mathrm{Sr}$ & $6.39 E+01$ & $4.68 \mathrm{E}-01$ & $8.40 E+01$ & $6.16 \mathrm{E}-01$ \\
\hline${ }^{90} y$ & $6.39 E+01$ & $1.17 \mathrm{E}-04$ & $8.40 E+01$ & $1.54 \mathrm{E}-04$ \\
\hline${ }^{137} \mathrm{Cs}$ & $4.89 E+01$ & $5.62 E-01$ & $6.42 E+01$ & $7.39 E-01$ \\
\hline${ }^{137} \mathrm{ma}$ & $4.62 E+01$ & $8.59 \mathrm{E}-08$ & $6.07 E+01$ & $1.13 \mathrm{E}-07$ \\
\hline${ }^{154} \mathrm{Eu}$ & $1.35 E+00$ & $5.00 E-03$ & $1.77 \mathrm{E}+00$ & $6.57 \mathrm{E}-03$ \\
\hline${ }^{155} \mathrm{Eu}$ & $7.62 \mathrm{E}-01$ & $1.64 \mathrm{E}-03$ & $1.00 E+00$ & $2.15 E-03$ \\
\hline${ }^{238} \mathrm{Pu}$ & $3.81 E+00$ & $2.23 \mathrm{E}-01$ & $5.01 E+00$ & $2.92 \mathrm{E}-01$ \\
\hline${ }^{239} \mathrm{Pu}$ & $1.50 E+01$ & $2.41 E+02$ & $1.97 \mathrm{E}+01$ & $3.17 E+02$ \\
\hline${ }^{240} \mathrm{Pu}$ & $8.23 E+00$ & $3.61 E+01$ & $1.08 \mathrm{E}+01$ & $4.75 E+01$ \\
\hline${ }^{241} \mathrm{Pu}$ & $3.26 \mathrm{E}+02$ & $3.16 \mathrm{E}+00$ & $4.28 \mathrm{E}+02$ & $4.16 E+00$ \\
\hline${ }^{242} \mathrm{Pu}$ & $2.51 \mathrm{E}-03$ & $6.57 \mathrm{E}-01$ & $3.30 \mathrm{E}-03$ & $8.64 \mathrm{E}-01$ \\
\hline${ }^{241} \mathrm{Am}$ & $2.90 \mathrm{E}+01$ & $8.45 \mathrm{E}+00$ & $3.81 E+01$ & $1.11 E+01$ \\
\hline${ }^{234} \mathrm{U}$ & $3.61 \mathrm{E}-02$ & $5.79 \mathrm{E}+00^{2}$ & $4.75 \mathrm{E}-02$ & $7.60 E+00$ \\
\hline${ }^{235} \mathrm{U}$ & $1.48 \mathrm{E}-03$ & $6.83 E+02^{2}$ & $1.94 \mathrm{E}-03$ & $8.97 E+02$ \\
\hline${ }^{236} \mathrm{U}$ & $5.35 \mathrm{E}-03$ & $8.27 \mathrm{E}+0 \mathrm{1}^{2}$ & $7.03 \mathrm{E}-03$ & $1.09 \mathrm{E}+02$ \\
\hline${ }^{238} \mathrm{U}$ & $2.69 \mathrm{E}-02$ & $8.00 E+04^{2}$ & $3.53 \mathrm{E}-02$ & $1.05 E+05$ \\
\hline Total & $6.08 \mathrm{E}+02$ & $8.11 \mathrm{E}+04$ & $7.99 E+02$ & $1.07 \mathrm{E}+05$ \\
\hline
\end{tabular}

${ }^{1}$ source: Short, S. M., 1995, Spent Nuclear Fuel Project Technical Databolok, WHC-SD-SNF-TI-015, Rev. 0, Westinghouse Hanford Company, Richland, Washington

(Table 3.10, wash pit column).

2values obtained from Table 2. 
Table 6. Mass and Activity, Total Sludge and Water (May 1993).

\begin{tabular}{|c|c|c|c|c|c|c|}
\hline \multirow[b]{2}{*}{ I sotope } & \multicolumn{3}{|c|}{ Activity (Ci) } & \multicolumn{3}{|c|}{ Mass (g) } \\
\hline & $\begin{array}{c}\text { sludge }{ }_{3} \\
\left(67.45 \mathrm{~m}^{3}\right)\end{array}$ & $\begin{array}{c}\text { Water }{ }^{2} \\
\left(157.4 \mathrm{~m}^{3}\right)\end{array}$ & $\begin{array}{c}\text { Total } \\
\left(224.83 \mathrm{~m}^{3}\right) \\
\end{array}$ & $\begin{array}{c}\text { sludge }{ }_{3}^{1} \\
\left(67.45 \mathrm{~m}^{3}\right)\end{array}$ & $\begin{array}{c}\text { Water }{ }^{2} \\
\left(157.4 \mathrm{~m}^{3}\right)\end{array}$ & $\begin{array}{c}\text { Total } \\
\left(224.83 \mathrm{~m}^{3}\right)\end{array}$ \\
\hline $3_{H}$ & & $2.39 E-04$ & $2.39 E-04$ & & $2.48 E-08$ & $2.48 \mathrm{E}-08$ \\
\hline${ }^{60} \mathrm{Co}$ & $3.82 E+01$ & & $3.82 E+01$ & $3.38 \mathrm{E}-02$ & & $3.38 \mathrm{E}-02$ \\
\hline${ }^{90} \mathrm{Sr}$ & $1.78 E+03$ & $1.31 E+00$ & $1.78 E+03$ & $1.30 E+01$ & $9.58 E-03$ & $1.30 E+01$ \\
\hline $90_{Y}$ & $1.78 E+03$ & $1.31 \mathrm{E}+00$ & $1.78 E+03$ & $3.26 \mathrm{E}-03$ & $2.40 \mathrm{E}-06$ & $3.27 E-03$ \\
\hline${ }^{137} \mathrm{cs}_{\mathrm{s}}$ & $1.35 E+03$ & $2.05 E+00$ & $1.35 E+03$ & $1.55 E+01$ & $2.35 \mathrm{E}-02$ & $1.55 E+01$ \\
\hline $137 \mathrm{~m}_{\mathrm{Ba}}$ & $1.28 E+03$ & $2.05 E+00$ & $1.28 E+03$ & 2.37E-06 & $3.80 \mathrm{E}-09$ & $2.37 \mathrm{E}-06$ \\
\hline $154 \mathrm{Eu}$ & $3.98 E+01$ & & $3.98 E+01$ & $1.47 \mathrm{E}-01$ & & $1.47 E-01$ \\
\hline${ }^{155_{\mathrm{Eu}}}$ & $2.27 E+01$ & & $2.27 E+01$ & $4.88 E-02$ & & $4.88 E-02$ \\
\hline${ }^{238} \mathrm{Pu}$ & $8.81 E+01$ & $1.57 \mathrm{E}-03$ & $8.81 E+01$ & $5.15 E+00$ & $9.15 E-05$ & $5.15 E+00$ \\
\hline${ }^{239} \mathrm{Pu}$ & $3.47 \mathrm{E}+02$ & $7.10 \mathrm{E}-03$ & $3.47 E+02$ & $5.59 E+03$ & $1.14 E-01$ & $5.59 \mathrm{E}+03$ \\
\hline $240 \mathrm{Pu}$ & $1.91 \mathrm{E}+02$ & $7.10 \mathrm{E}-03$ & $1.91 E+02$ & $8.38 \mathrm{E}+02$ & $3.12 \mathrm{E}-02$ & $8.38 E+02$ \\
\hline $241_{\mathrm{Pu}}$ & $7.56 \mathrm{E}+03$ & & $7.56 \mathrm{E}+03$ & $7.34 E+01$ & & $7.34 E+01$ \\
\hline${ }^{242} \mathrm{Pu}$ & $5.82 \mathrm{E}-02$ & & $5.82 E-02$ & $1.52 \mathrm{E}+01$ & & $1.52 \mathrm{E}+01$ \\
\hline $241^{A m}$ & $1.03 E+03$ & $3.26 \mathrm{E}-02$ & $1.03 E+03$ & $2.99 \mathrm{E}+02$ & $9.49 \mathrm{E}-03$ & $2.99 E+02$ \\
\hline${ }^{234} \mathrm{U}$ & $8.72 \mathrm{E}-01$ & $1.95 \mathrm{E}-05$ & 8.72E-01 & $1.40 \mathrm{E}+02$ & $3.12 E-03$ & $1.40 \mathrm{E}+02$ \\
\hline $235 \mathrm{u}$ & $3.56 \mathrm{E}-02$ & $7.95 E-07$ & $3.56 \mathrm{E}-02$ & $1.65 E+04$ & $3.68 \mathrm{E}-01$ & $1.65 E+04$ \\
\hline $236 \mathrm{U}$ & $1.29 \mathrm{E}-01$ & $2.88 \mathrm{E}-06$ & $1.29 \mathrm{E}-01$ & $2.00 E+03$ & $4.45 E-02$ & $2.00 E+03$ \\
\hline${ }^{238} \mathrm{u}$ & $6.49 E-01$ & $1,45 E-05$ & $6.49 E-01$ & $1.93 E+06$ & $4.31 E+01$ & $1.93 E+06$ \\
\hline${ }^{231} \mathrm{Th}^{3}$ & & & $3.56 \mathrm{E}-02$ & & & $6.70 E-08$ \\
\hline${ }^{234} T h^{3}$ & & & $6.50 E-01$ & & & $2.80 E-05$ \\
\hline${ }^{233} \mathrm{~Pa}^{3}$ & & & $3.47 \mathrm{E}-03$ & & & $1.67 \mathrm{E}-07$ \\
\hline${ }^{234} \mathrm{pa}^{3}$ & & & $8.44 E-04$ & & & $4.22 E-10$ \\
\hline $234 m_{P a} 3$ & & & $6.50 \mathrm{E}-01$ & & & $9.45 E-10$ \\
\hline Total & $1.55 E+04$ & $6.75 E+00$ & $1.55 E+04$ & $1.96 E+06$ & $4.37 \mathrm{~F}+01$ & $1.96 E+06$ \\
\hline
\end{tabular}

1 Values from Table 3 .

${ }^{2}$ values form Table 4.

3 Additional Actinides, calculated by Origen2, decayed ten years. 


$$
\text { WHC-SD-TP-PDC-035 Rev. } 0
$$

Table 7. Mass and Activity, Single Shipment, Worst Case (May 1993).

\begin{tabular}{|c|c|c|c|c|c|c|}
\hline \multirow[t]{2}{*}{ Isotope } & \multicolumn{3}{|c|}{ Activity (Ci) } & \multicolumn{3}{|c|}{ Mass (g) } \\
\hline & $\begin{array}{l}\text { sludge } \\
\left(1.8 \mathrm{~m}^{3}\right) \\
\end{array}$ & $\begin{array}{c}\text { Water }{ }^{2} \\
\left(4.2 \mathrm{~m}^{3}\right)\end{array}$ & $\begin{array}{r}\text { Total } \\
\left(6.0 \mathrm{~m}^{3}\right) \\
\end{array}$ & $\begin{array}{l}\text { sludge } \\
\left(1.8 \mathrm{~m}^{3}\right)\end{array}$ & $\begin{array}{l}\text { Water }{ }^{2} \\
\left(4.2 \mathrm{~m}^{3}\right) \\
\end{array}$ & $\begin{array}{c}\text { Total } \\
\left(6.0 \mathrm{~m}^{3}\right)\end{array}$ \\
\hline $3_{H}$ & & $6.38 E-06$ & $6.38 E-06$ & & $6.62 \mathrm{E}-10$ & $6.62 E-10$ \\
\hline${ }^{60} \mathrm{Co}$ & $1.68 E+00$ & & $1.68 \mathrm{E}+00$ & $1.49 E-03$ & & $1.49 E-03$ \\
\hline${ }^{90} \mathrm{Sr}$ & $8.40 E+01$ & $3.49 \mathrm{E}-02$ & $8.40 \mathrm{E}+01$ & $6.16 \mathrm{E}-01$ & $2.56 \mathrm{E}-04$ & $6.16 \mathrm{E}-01$ \\
\hline $90 y$ & $8.40 E+01$ & $3.49 E-02$ & $8.40 E+01$ & $1.54 E-04$ & $6.41 \mathrm{E}-08$ & $1.54 \mathrm{E}-04$ \\
\hline $137 \mathrm{cs}$ & $6.42 E+01$ & $5.46 \mathrm{E}-02$ & $6.43 \mathrm{E}+01$ & $7.39 E-01$ & $6.28 E-04$ & $7.39 \mathrm{E}-01$ \\
\hline $137 \mathrm{~m}_{\mathrm{Ba}}$ & $6.07 E+01$ & $5.46 \mathrm{E}-02$ & $6.08 \mathrm{E}+01$ & $1.13 E-07$ & $1.02 E-10$ & 1. $13 \mathrm{E}-07$ \\
\hline${ }^{154} \mathrm{Eu}$ & $1.77 E+00$ & & $1.77 \mathrm{E}+00$ & $6.57 E-03$ & & $6.57 E-03$ \\
\hline${ }^{155} \mathrm{Eu}$ & $1.00 E+00$ & & $1.00 \mathrm{E}+00$ & $2.15 E-03$ & & $2.15 E-03$ \\
\hline${ }^{238} \mathrm{Pu}$ & $5.01 E+00$ & $4.18 E-05$ & $5.01 \mathrm{E}+00$ & $2.92 E-01$ & $2.44 E-06$ & $2.92 \mathrm{E}-01$ \\
\hline${ }^{239} \mathrm{Pu}$ & 1.97E+01 & $1.89 E-04$ & $1.97 E+01$ & $3.17 E+02$ & $3.05 E-03$ & $3.17 E+02$ \\
\hline $240 \mathrm{Pu}$ & $1.08 \mathrm{E}+01$ & $1.89 \mathrm{E}-04$ & $1.08 E+01$ & $4.75 E+01$ & $8.31 E-04$ & $4.75 E+01$ \\
\hline $241 \mathrm{Pu}$ & $4.28 E+02$ & & $4.28 \mathrm{E}+02$ & $4.16 E+00$ & & $4.16 \mathrm{E}+00$ \\
\hline $242 \mathrm{Pu}$ & $3.30 E-03$ & & $3.30 E-03$ & $8.64 E-01$ & & $8.64 E-01$ \\
\hline $241_{\mathrm{Am}}$ & $3.81 E+01$ & $8.69 E-04$ & $3.81 E+01$ & $1.11 E+01$ & $2.53 E-04$ & $1.11 \mathrm{E}+01$ \\
\hline${ }^{234} \mathrm{U}$ & $4.75 \mathrm{E}-02$ & $5.19 \mathrm{E}-07$ & $4.75 E-02$ & $7.60 \mathrm{E}+00$ & $8.31 E-05$ & $7.60 E+00$ \\
\hline $235 \mathrm{U}$ & $1.94 \mathrm{E}-03$ & $2.12 E-08$ & $1.94 E-03$ & $8.97 \mathrm{E}+02$ & $9.81 \mathrm{E}-03$ & $8.97 E+02$ \\
\hline $236 \mathrm{U}$ & $7.03 \mathrm{E}-03$ & $7.69 \mathrm{E}-08$ & $7.03 E-03$ & $1.09 \mathrm{E}+02$ & $1.19 \mathrm{E}-03$ & $1.09 \mathrm{E}+02$ \\
\hline $238 \mathrm{U}$ & $3.53 \mathrm{E}-02$ & $3.87 \mathrm{E}-07$ & $3.53 E-02$ & $1.05 E+05$ & $1.15 E+00$ & $1.05 E+05$ \\
\hline${ }^{231} \mathrm{Th}^{3}$ & & & $1.94 \mathrm{E}-03$ & & & $3.65 \mathrm{E}-09$ \\
\hline${ }^{234} \mathrm{Th}^{3}$ & & & $3.54 E-02$ & & & $1.53 E-06$ \\
\hline${ }^{233} \mathrm{~Pa}^{3}$ & & & $1.32 \mathrm{E}-04$ & & & $6.36 E-09$ \\
\hline${ }^{234} \mathrm{~Pa}^{3}$ & & & $4.60 E-05$ & & & $2.30 E-11$ \\
\hline $234 \mathrm{~m}_{\mathrm{Pa}} 3$ & & & $3.54 E-02$ & & & $5.15 E-11$ \\
\hline Total & $7.99 \mathrm{E}+02$ & $1.80 \mathrm{E}-01$ & $8.00 \mathrm{E}+02$ & $1.07 E+05$ & $1.17 E+00$ & $1.07 \mathrm{E}+05$ \\
\hline
\end{tabular}

1 Values from Table 5 .

ZValues form Table 4.

3 Additional actinides, calculated by origen2, decayed ten years. 


\subsection{CHEMICAL COMPOSITION} Chemical inventory of the sludge is provided in Table 8 (Short 1995 ),
plus the following elements (as isotopes): ${ }^{241} \mathrm{Am},{ }^{137} \mathrm{Cs},{ }^{154} \mathrm{Eu}$ and ${ }^{155} \mathrm{Eu},{ }^{96} \mathrm{Sr}$ and ${ }^{90} Y$ (from Table 3 ).

Table 8. Chemical Constituents in K East Basin Sludge.*

\begin{tabular}{|c|c|c|c|c|c|c|c|}
\hline Chemical & Total (kg) & Chemical & Total $(\mathrm{kg})$ & Chenical & Total (kg) & Chemical & Total (kg) \\
\hline Al & $5.82 \mathrm{E}+02$ & $\mathrm{Cu}$ & $9.14 E+00$ & Nd & $3.45 E+00$ & $\$ r$ & 8.42E-01 \\
\hline As & $1.11 \mathrm{E}+00$ & $\mathrm{Fe}$ & $6.20 E+03$ & $\mathrm{Ni}$ & $2.42 E+00$ & $\mathrm{Ti}$ & $3.57 \mathrm{E}+00$ \\
\hline $\mathrm{Ba}$ & $2.93 E+00$ & K & $4.05 E+00$ & $\mathbf{P}$ & $1.08 \mathrm{E}+01$ & TI & $3.93 E+00$ \\
\hline $\mathrm{Be}$ & 2. 18E-01 & Li & $1.97 E+00$ & $\mathrm{~Pb}$ & $1.29 \mathrm{E}+01$ & v & $9.60 \mathrm{E}+00$ \\
\hline $\mathrm{Ca}$ & $1.11 E+02$ & $\mathrm{Mg}$ & $2.49 \mathrm{E}+01$ & $s$ & $8.79 E+00$ & $2 n$ & $2.64 E+01$ \\
\hline Cd & $2.39 E+00$ & $M n$ & $9.43 E+00$ & sb & $5.57 \mathrm{E}+00$ & $2 r$ & $4.38 E+00$ \\
\hline Co & $5.66 E-01$ & Mo & $9.52 \mathrm{E}-01$ & si & $4.86 \mathrm{E}+01$ & $\underline{U}$ & 2. $00 \mathrm{E}+03$ \\
\hline $\mathrm{Cr}$ & $2.34 E+01$ & $\mathrm{Na}$ & $4.94 E+00$ & Sim & $1.23 E+01$ & Pu & $6.73 E+00$ \\
\hline other & $2.31 E+04$ & & & & & Total & $3.22 E+04$ \\
\hline
\end{tabular}

*Source: Short, S. M., 1995, Spent Nuclear Fuel Project Technical Databook, WHC-SD-SNF-TI-015, Rev. O West inghouse Hanford Company, Richland, Washington. See also, Section 2.4 for additional elements.

The sludge has an in situ $\mathrm{pH}$ range of 5 to 9 . After it is loaded into the transport container, the chemistry will be adjusted to meet TWRS storage tank chemical acceptance criteria shown in Table 9.

Tabie 9. 0SD-T-151-00007 Limits.

\begin{tabular}{|c|c|}
\hline Constituent & Limit (M) \\
\hline \multicolumn{2}{|r|}{$\left[\mathrm{NO}_{3}\right] \leq 1.0 \mathrm{M}$} \\
\hline Hydroxide & $0.01 \mathrm{M} \leq[\mathrm{OH}] \leq 5.0$ \\
\hline Nitrite & $0.011 \leq\left[\mathrm{NO}_{2}\right] \leq 5.5$ \\
\hline \multicolumn{2}{|c|}{$1.0 \mathrm{M} \leq\left[\mathrm{NO}_{3}\right] \leq 3.0 \mathrm{M}$} \\
\hline Hydroxide & $0.1 \times\left[\mathrm{NO}_{3}\right] \leq[\mathrm{OH}]<10$ \\
\hline Nitrite & {$[\mathrm{OH}]+\left[\mathrm{NO}_{2}\right] \geq 0.4 \times\left[\mathrm{NO}_{3}\right]$} \\
\hline \multicolumn{2}{|r|}{$\left[\mathrm{NO}_{3}\right]>3.0 \mathrm{M}$} \\
\hline Hydroxide & $0.3 \leq[\mathrm{OH}]<10$ \\
\hline Nitrite & {$[\mathrm{OH}]+\left[\mathrm{NO}_{2}\right] \geq 1.2$} \\
\hline Nitrate & {$\left[\mathrm{NO}_{3}\right]<5.5 \mathrm{M}$} \\
\hline
\end{tabular}


WHC-SD-TP-PDC-035 Rev. 0

\subsection{TRANSPORTATION CLASS}

The worst-case payload contains $15,200 \mathrm{~A}_{2} \mathrm{~S}$, a Type $\mathrm{B}$, highway route controlled quantity ( $H R C Q$ ), fissile material. The $A_{2} s$ are taken from the revised Table A-1 of 10 CFR 71 , effective date April 1996.

\subsection{THERMAL DESCRIPTION}

The sludge heat generation rate averaged over the entire $K$ East Basin sludge inventory is $187 \mathrm{BTU} / \mathrm{h}(54.8 \mathrm{~W})$. The decay heat for the worst-case single shipment using the inventory of Table 7 is $11.16 \mathrm{BTU} / \mathrm{h}(3.27 \mathrm{~W})$.

The temperature of the sludge is expected to be approximately the same as the basin water temperature: $6{ }^{\circ} \mathrm{C}$ to $32{ }^{\circ} \mathrm{C}\left(42^{\circ} \mathrm{F}\right.$ to $\left.90^{\circ} \mathrm{F}\right)$. Basin water temperature is usually maintained at approximately $10^{\circ} \mathrm{C}\left(50^{\circ} \mathrm{F}\right)$.

\subsection{GAS GENERATION}

Sludge and water mixtures may produce gases from fission gas release, radiolysis, and uranium reaction with water. Radiolysis and uranium/water reactions produce hydrogen gas. Refer to Section 5.1 .7 for the gas generation analysis requirements and operating pressure limits.

\subsection{FACILITY OPERATIONS AND INTERFACES}

The packaging and transport system shall be compatible with the sludge offload equipment and system operations at the $K$ Basins and the AW Tank Farm.

It is anticipated that the entire sludge removal campaign will involve 70-100 shipments over a three-year period. The shipment route will be southeast from the K Basins; east on Route 1; south on Route $4 S$ to 200 East Area; east on 4th Street; around AP Tank Farm to the east gate of AW Tank Farm; through the east gate to a DST staging area, for a one-way total distance of $18 \mathrm{~km}$ (11 $\mathrm{mi})$. The route is located entirely within the Hanford Site boundary. Because a radioactive heel of unknown size will reside within the container during its return trip, the accident risk analysis, Section 5.1.2, shall take into account return mileage.

\subsection{ORIGINATING FACILITY}

The loading of the sludge container will take place within a covered loadout area, yet to be defined, adjacent to the $K$ East Basin. The packaging and transport trailer will arrive as a single-unit, fixed system; the container will not be removed from the trailer during loading operations.

The sludge chemistry will be adjusted at the $K$ East Basin to meet AW Farm waste acceptance criteria prior to transport. The container shall include a means to mix the contents following chemical addition. 
WHC-SD-TP-PDC-035 Rev. O

The payload in the container shall be monitored and controlled to ensure that the maximum gross weights (Section 4.2 .7 ) and radiation levels (Section 4.2.8) are not exceeded.

A sample may be obtained and sent to the 222-S Laboratory for analysis to verify container contents. A nondestructive assay (NDA) will be performed to determine curie content of certain radionuclides residing in the filled container.

\subsection{RECEIVING FACILITY}

The receiving facility is currently planned to be a DST located in the 200 East Area. The packaging and transport trailer will arrive as a singleunit, fixed system; the container will not be removed from the trailer during unloading operations. The tank farm will be modified to provide a spill retention basin and a 7.6-cm (3-in.) double-encased pipe with valving, leak detection, and a mating connector to connect to the container's sludge removal system. Leak detectors will be interlocked to the sludge removal pump. Flush water and electrical power will be provided by the receiving facility. However, the transport system shall provide the equipment necessary to interface with tank farm utilities. If process air is required, it shall be provided with the transport system. Once the majority of sludge is pumped from the container, the residual heel will be sluiced from the container. Following sluicing, the transfer lines will be flushed, and the transport system will be disconnected from the receiving facility.

Current TWRS DST receiving constraints are that the plutonium concentration be 1 imited to $0.5 \mathrm{~g} / \mathrm{L}$ maximum and that the solids-to-plutonium weight ratio be greater than 1,000. A preliminary study (Precechtel 1995) shows that sludge concentrations of less than $80 \%$ by weight meet the TWRS DST receiving criteria. A transfer limit of $6 \mathrm{Ci} / 3.79 \mathrm{~L}(6 \mathrm{Ci} / \mathrm{gal}$ ) applies to DSTs in the AW Tank Farm. Additional chemistry constraints are given in Section 2.4.

Communication between the transport system and Tank Farm Operations will be maintained at all times during transfers.

\subsection{PACKAGING/TRANSPORT SYSTEM DESIGN CRITERIA}

\subsection{GENERAL}

The packaging and trailer shall be designed and delivered as a system, with all support hardware (Section 4.4) furnished and attached. Where deemed necessary for operational/as low as reasonably achievable (ALARA) considerations, the purchaser shall consider the need for a catch-basin/liquid retention system be in place on board the trailer to mitigate the effects of an unexpected spill or liquid loss. 
WHC-SD-TP-PDC-035 ReV. 0

The functional requirements for the packaging and transport system are as follows:

- Interface with and fit within the $\mathrm{K}$ Basin loadout facility

- Receive and contain $K$ Basin sludge and water

- Travel to a TWRS DST in the 200 Area while loaded with sludge and water

- Interface with and fit within the TWRS offload facility

- Return travel to the K Basin after bulk sludge is offloaded

- Be operable under the ambient conditions given in Tables 13 and 14

- Provide for safe shutdown of equipment during sludge removal activities in the event of equipment failure; i.e., leakage

- Include features to accept sludge from the loadout system and remove the sludge from the container while minimizing the spread of contamination during coupling/uncoupling operations

- Facilitate decontamination. The interior and exterior surfaces of the container shall be smooth and essentially impermeable to radioactive contamination and buildup

- Meet ALARA radiation objectives per Bergsman (1996); the Hanford Site "Master Safety Rules" referenced in WHC-CM-1-10, Safety Manua7; and Occupational Safety and Health Administration (OSHA) standards per 29 CFR 1910.

\subsection{PACKAGING AND CONTAINER}

The packaging shall meet onsite Type $B$ HRCQ performance criteria. The container shall be an ASME pressure vessel, designed, fabricated and certified to ASME (1992), Section VIII. Analysis of the container may be performed in lieu of actual testing.

\subsubsection{General Requirements}

The container shall meet the transportation safety requirements of Section 5.1 and the following performance requirements:

- Fit within the dimensional confines given in Section 4.2 .5 and weigh no more than specified in Table 12 (fully loaded container and all support hardware)

- Be compatible with the $\mathrm{pH}$ range and mixture of chemical constituents identified in Sections 2.2 and 2.4 
WHC-SD-TP-PDC-035 Rev. 0

- Be "leak-testable" (able to accommodate leak testing) per ANSI N14.5 (ANSI 1987), Sections 6.3.1 and 6.5.

- Include features to localize and minimize the size of the sludge heel (such as would be provided by a sloped bottom)

- Include features, such as damping, to mitigate the effects of water sloshing

- Include a means for chemical-addition to adjust contents to meet the chemical acceptance criteria (Section 2.4)

- Include features to obtain sludge samples for laboratory analyses

- Include features to insta11 NDA instrumentation

\subsubsection{Loading and Unloading}

The transport system shall be compatible with the sludge loadout system located at the $\mathrm{K}$ Basin and the sludge offload system at the TWRS AW Tank Farm.

The maximum container fill rate is anticipated to be $100 \mathrm{gal} / \mathrm{min}$ $(6.3 \mathrm{~L} / \mathrm{s})$ through a $5.1-\mathrm{cm}(2-i n$.$) fill line. The fill line shall connect to$ the container fill port using a dry disconnect coupler. Air displaced from the container during filling and discharging operations shall be vented through at least two, passive, HEPA-filtered vents that are capable of being sealed during transport. During loading, the container will be monitored to control sludge volume and fissile content, using level detectors and NDA instrumentation features that will be interlocked with the loadout system.

After the sludge is loaded into the container, it will be chemically adjusted to meet AW Tank Farm waste acceptance criteria.

At the time of removal from the basin, the sludge characteristics shall be compared to the operational safety limits established in the SARP, using NDA or actual laboratory analyses of samples. Safety 1 imits of

Sections 5.1.3, 5.1.4, 5.1.5, and 5.1.7, as finalized in the SARP, shall not be exceeded.

Container contents will be unloaded via the sludge offload system, using a pumping system provided as part of the transport system. The transport system shall mate with a 7.6-cm (3-in.) transfer line via a dry disconnect coupler and have its controls interlocked with the sludge offload system leak detection equipment. The transport system shall include equipment to connect to TWRS-supplied utilities; i.e., electrical, flush water.

\subsubsection{Material Requirements}

Packaging materials shall be American Society for Testing and Materialscertified materials. 


$$
\text { WHC-SD-TP-PDC-035 Rev. } 0
$$

Packaging materials shall be compatible with the sludge such that any chemical, galvanic, and corrosive reactions occurring between the packaging and the sludge do not limit the service life stated in Section 4.2.12. Where necessary, sufficient corrosion allowance shall be provided. Materials shall be of suitable surface finish to accommodate decontamination.

\subsubsection{Fabrication Methods}

The pressure-vessel container shall be fabricated in accordance with ASME (1992), Section VIII, in accordance with the manufacturer's established fabrication, inspection, and testing programs, according to the guidelines of WHC-CM-4-2.

Welding, welder/welding operator qual ifications, and weld inspection shall be per ASME (1992), Section VIII.

\subsubsection{Dimensions and Volume}

The packaging shall be sized such that the maximum gross weights (Section 4.2.7) and radiation levels (Section 4.2.8) are not exceeded and such that the number of shipments is minimized. The minimum container size shall be $3 \mathrm{~m}^{3}$ and the maximum size shall be $6 \mathrm{~m}^{3}$. The packaging shall fit within the confines of an $2.44 \mathrm{~m}(8 \mathrm{ft})$ wide, single-drop, flatbed trailer and shall rest on the drop deck. The trailer and packaging shall have a maximum combined overall height not to exceed $3.66 \mathrm{~m}(12 \mathrm{ft})$. Trailer dimensional requirements are shown in Table 12 .

\subsubsection{Weight of Contents}

For a maximum payload of $6 \mathrm{~m}^{3}$, the weight of the contents is expected to be approximately $6,985 \mathrm{~kg}(15,400 \mathrm{lb})$. The payload will consist of up to $30 \%$ sludge by volume, the rest being interstitial basin and process water. Refer to Section 2.1 for a description of the payload.

\subsubsection{Maximum Gross Weight}

The maximum combined weight of the trailer, packaging, payload, and support equipment shall be per Table 12. The actual individual weights of the trailer, packaging, and support equipment shall be determined and recorded by the supplier for use during the crush analysis of Section 5.1.2.

\subsubsection{Shielding Requirements}

Shielding thickness shall be based on the highest specific-activity sludge, with the sludge settled to the bottom of the container. Shielding may be integral with the container or may be provided exterior to the package. If lead is used, it shall be isolated from contact with radioactive material. Shielding shall be provided to meet the radiation dose rate limits of 
Section 5.1.4, except that the more restrictive operations-control design 1 imit of $100 \mathrm{mrem} / \mathrm{h}$ at any point on the external surface of the package shall apply.

\subsubsection{Ports, Seals, and Closures}

Packaging ports and closures are to be sealed from the atmosphere during transport with positive closure devices. Closure devices shall not be able to be opened unintentionally. Seals and closure devices must remain functional during the normal and accident conditions described in Sections 5.1.1 and 5.1.2. Seals and sealing surfaces shall have a means of being protected during equipment handling processes.

\subsubsection{Venting and Filters}

The packaging container shall have at least two passive HEPA-filtered vents. The HEPA filters shall be of a standard size and be constructed of materials compatible with water. The size, number, and location shall be determined by the gas generation analysis (Section 5.1.7) and the filling and discharge rates. The filter system (Section 4.4 ) shall be sealed from the atmosphere while the package is under transport.

\subsubsection{Heel Minimization and Removal}

The container shall be designed to minimize the size of the sludge heel, consistent with the ALARA goals of Section 5.2. The container interior shal1 be designed in a manner that allows for removal of the majority of sludge heel, including particles as large as $0.64 \mathrm{~cm}$ (0.25 in.).

\subsubsection{Service Life}

The minimum service life of the packaging shall be 20 years. Service life of routine-maintenance components, interior and exterior to the container, shall be maximized, thereby reducing radiation exposure.

\subsubsection{Decontamination}

Prior to transport, smearable contamination on the external surfaces of the packaging shall be removed to within the limits of Table 10 . The external surfaces of the packaging shall be designed to facilitate contamination removal. Internal surfaces of the container shall be essentially resistant to radioactive buildup and shall facilitate cleanup by water spray. Interior surface contours shall minimize sludge trapping and shall accommodate flushing to a retrieval point. 
WHC-SD-TP-PDC-035 Rev. 0

Table 10. Packaging External Decontamination Limits.

\begin{tabular}{|c|c|c|}
\hline \multirow[t]{2}{*}{ Contaminant } & \multicolumn{2}{|c|}{ Maximum permissible limits } \\
\hline & $\mu \mathrm{Ci} / \mathrm{cm}^{2}$ & $\mathrm{dpm} / \mathrm{cm}^{2}$ \\
\hline $\begin{array}{l}\text { Beta-gamma emitting radionuclides; all radionuclides with } \\
\text { half-lives less than ten days; natural uranium; natural } \\
\text { thorium; uranium-235; uranium-238; thorium-232; thorium- } \\
228 \text { and thorium-230 when contained in ores or physical } \\
\text { concentrates }\end{array}$ & $10^{-5}$ & 22 \\
\hline All other alpha emitting radionuclides & $10^{-6}$ & 2.2 \\
\hline
\end{tabular}

Source: 49 CFR 173.443(a), 1994, "Transportation," Code of Federal Regulations, as amended.

\subsubsection{Tiedown and Lifting Attachments}

The packaging (Section 4.0) shall be attached to the trailer by tiedowns and/or a blocking and bracing system. Structural parts of the packaging that could be used as a tiedown point(s), but are not designed as such, shall be rendered inoperable during transport. The tiedown and/or blocking and bracing system design shall accommodate the following $g$ factors, applied to the weight of a fully loaded package including all attached support hardware.

Any tiedown attachment point on the package shall not cause package failure when the package is subjected to a static force positioned at its center of gravity, having the following loading:

- A vertical component of $2 g$

- A horizontal component along the direction of vehicle travel of $10 \mathrm{~g}$

- A horizontal component perpendicular to the direction of vehicle travel of $5 \mathrm{~g}$.

Lifting attachments, to $1 \mathrm{ift}$ the container itself, shall be designed such that their failure will not impair the package integrity and shall have a safety factor of at least three (3) applied to yield. Any structural part of the package not approved for lifting the container shall be rendered inoperable for lifting. In operation, the container will reside permanently on the trailer and will not be removed.

\subsubsection{Containment Boundary}

The containment boundary is provided by the sludge container. 


$$
\text { WHC-SD-TP-PDC-035 Rev. } 0
$$

\subsection{TRANSPORT TRAILER}

\subsubsection{General Requirements}

The trailer shall meet the following requirements:

- Be a National Highway Traffic Safety Administration-registered trailer meeting the minimum design requirements of Section 4.3

- Be an open lowboy, single drop, $12.2 \mathrm{~m}$ (40 ft) long overal1, and $2.4 \mathrm{~m}(8 \mathrm{ft})$ wide

- Accommodate the concentrated load of the container full of sludge and water and attached equipment (estimated at $27,216 \mathrm{~kg}$ $[60,000 \mathrm{lb}]$, minimum)

- Have packaging attachment cross members meeting the securement systems requirements of 49 CFR 393.102(d)

- Have a factor of safety with respect to yield strength of $2: 1$ for the concentrated load.

- Be operable under the ambient conditions specified in Tables 13 and 14 .

Prior to delivery, the trailer shall demonstrate acceptance at the Seller's facility by being subjected to both a static and a rolling road test carrying weight equal to the actual distributed load.

\subsubsection{Regulatory Requirements}

The trailer shall comply with the federal regulations and standards listed in Table 11 and shall comply with all current applicable federal and Washington state regulations at time of manufacture.

Table 11. Trailer Regulatory Standards. (2 sheets total)

\begin{tabular}{|l|l|}
\hline \multicolumn{1}{|c|}{ Part } & \multicolumn{1}{|c|}{49 CFR--current issue, including revisions } \\
\hline 566 & Manufacturer identification \\
\hline 567 & Certification \\
\hline 393 & Parts and accessories necessary for safe operation \\
\hline 172, Appendix C & Dimensional specifications for recommended placard holder \\
\hline
\end{tabular}


Table 11. Trailer Regulatory Standards. (2 sheets total)

\begin{tabular}{|c|c|c|}
\hline Part & & 9 CFR--current issue, including revisions \\
\hline \multirow[t]{8}{*}{571} & \multicolumn{2}{|c|}{$\begin{array}{l}\text { Federal motor vehicle safety standards--vehicle safety } \\
\text { standards developed by the U.S. Department of } \\
\text { Transportation for commercial vehicle certification with } \\
\text { the National Highway Traffic Safety Administration }\end{array}$} \\
\hline & Section & Title \\
\hline & 106 & Brake hose \\
\hline & 108 & $\begin{array}{l}\text { Lamps, reflective devices, and associated } \\
\text { equipment }\end{array}$ \\
\hline & 115 & Vehicle identification number \\
\hline & 119 & $\begin{array}{l}\text { New pneumatic tires for vehicles other than } \\
\text { passenger cars }\end{array}$ \\
\hline & 120 & $\begin{array}{l}\text { Tire selection and rims for motor vehicles other } \\
\text { than passenger cars }\end{array}$ \\
\hline & 121 & Air brake systems \\
\hline
\end{tabular}

\subsubsection{Weight and Dimensional Requirements}

The trailer, with a fully loaded package and all support hardware attached, shall not exceed the requirements of Table 12. In addition, if reasonabiy feasible, the trailer's maximum gross loaded weight (with the maximum sized payload) shall have a design goal weight 1 imit of $36,287 \mathrm{~kg}$ $(80,000 \mathrm{1b})$.

Table 12. Trailer Characteristics.

\begin{tabular}{|l|l|}
\hline Maximum gross loaded weight without tractor & $45,359 \mathrm{~kg}(100,000 \mathrm{lb})$ \\
\hline Maximum length & $12.2 \mathrm{~m}(40 \mathrm{ft})$ \\
\hline $\begin{array}{l}\text { Maximum overall height including packaging } \\
\text { and all attached support equipment }\end{array}$ & $366 \mathrm{~cm}(12 \mathrm{ft})$ \\
\hline Maximum height of drop deck & $55.9 \mathrm{~cm}(22 \mathrm{in.})$ \\
\hline Maximum width & $2.4 \mathrm{~m}(8 \mathrm{ft})$ \\
\hline
\end{tabular}

\subsubsection{Material and Structural Requirements}

Trailer materials shall comply with American Society for Testing and Materials (ASTM) or American Institute of Steel Construction (AISC) standards.

All structural components must meet (at least) a 2:1 factor of safety on yield strength. 
The main frame shall be an inboard I-beam design or equal. Web stiffeners shall be used at high-load points.

Requirements are as follows.

- Cross bearers shall be heavy-duty " $C$ " channel cross members with a stabilizing return lip on the top flange (or equivalent).

- Front cross member shall be $0.48-\mathrm{cm}(0.1875-$ in.) formed section having smooth top and bottom edges (or equivalent).

- Upper coupler shall be 0.64-cm- (0.25-in.-) thick pickup plate supported by a ful1-depth cross-member box assembly (or equivalent).

- Pickup plate shall have gusseted turnup lip, or equivalent protection, for the front cross member and glad hands during tractor coupling.

- The wheel area shall have a running gear frame of welded I-beam (or equivalent).

\subsubsection{Trailer Tiedown Structures}

The trailer tiedown structure shall be of sufficient strength to preclude yielding of material in the trailer tiedown devices, the blocking and bracing devices, the trailer attachment points, and the trailer itself when subjected to the dynamic loading of Section 4.2.14.

Trailer tiedowns shall also not yield under the following load factor requirements of IAEA (1990) Safety Series 37:

- A vertical component of $3 g$ down, $2 g$ up

- A horizontal component along the direction of vehicle travel of $\pm 2 g$

- A horizontal component perpendicular to the direction of vehicle travel of $\pm 1 \mathrm{~g}$.

\subsubsection{Landing Gear}

The landing gear shall have a two-speed, manual crank with sand pads capable of accommodating a fully loaded trailer. Sand pads shall be sized so as not to sink into asphalt and the spill-pad geotextile under the ambient conditions of Tables 13 and 14 .

\subsubsection{Suspension}

The trailer suspension shall be capable of handling a concentrated container, fully loaded (estimated at $27,216 \mathrm{~kg}(60,000 \mathrm{lb}))$, plus the weight of all support equipment, and shall have readily available replacement parts for maintenance. 
Requirements are as follows.

- The suspension shall be an air ride system.

- The number of axles shall be minimized, with a minimum load capacity of $10,206 \mathrm{~kg}(22,500 \mathrm{lb})$ each, and shall be furnished with oil seals.

- The wheels shall be disc wheels, 10 hole, painted according to Section 4.3 .11 .

- The tires shall be $255 / 70 R \times 22.5$, radial type (or equivalent).

\subsubsection{Brake System}

The brakes shall be an air brake system, S-cam type, air actuated, with type 30 brake chambers that drive $15.2-\mathrm{cm}(6-i n$.$) automatic slack adjusters.$ Air system hoses sha11 meet FMVSS-121 and FMVSS-106 standards. G1ad hands shall be centered on the front cross member, and dummy glad hands shall be provided.

\subsubsection{King Pin}

A Society of Automotive Engineers (SAE) king pin shall be welded to the pickup plate and reinforced by $0.95-\mathrm{cm}-(0.375-i n .-)$ thick vertical stiffeners (or equivalent). The king pin diameter shall be $6.35 \mathrm{~cm}(2.5 \mathrm{in}$.). The king pin height shall be $122-127 \mathrm{~cm}$ (48-50 in.). The king pin setting shall be $76.2 \mathrm{~cm}$ (30 in.), or industry equivalent, to provide a swing clearance of $178-188 \mathrm{~cm}(70-74 \mathrm{in.})$.

\subsubsection{Lighting}

The lighting system shall conform to FMVSS-108 and shall incorporate light-emitting diode lamps. Connections shal1 be seven-way standard contact. All wiring shall be sealed in metal or plastic conduit and routed, secured, and protected from abrasion and chafing.

\subsubsection{Painting}

The trailer and wheels shall be primed and painted with products suitable for disposal as non-hazardous waste at the Hanford site. One product that currently meets this requirement is Amercoat* 450-HS. Both the primer and finish coats shall be applied according to manufacturer's instructions, with a minimum of two finish coats of white color (Amercoat white product code RT-8301). Prior to priming, surfaces shall be clean and free of weld slag and other foreign materials.

*Amercoat is a trademark of American Paint Corporation, Leominster, MA. 
WHC-SD-TP-PDC-035 Rev. 0

\subsubsection{Service Life and Additional Requirements}

- The trailer shall have a service life of 20 years.

- The bumper (rear-end protection) height and width shall comply with 49 CFR 393.86.

- There shall be two mud flaps and anti-sail spray guards at rear wheel areas.

- There shall be four metal flip-frame type placards designed and placed on the trailer per 49 CFR 172.500, Subpart F, "Placarding."

- The trailer shall be capable of being washed down with high-pressure water.

- The trailer shall have rub rails with stake pocket capability located on each side and each end of the trailer. Rub rails shall be welded on.

- The trailer shall have working decks covered with $0.48-\mathrm{cm}$ (0.1875-in.) stainless steel diamond plate.

- The trailer welding, weld joint preparation, cleaning, welding procedures, welder qualifications, and inspections shall be in accordance with ANSI/AWS D1.1 for steel (ANSI/AWS 1989c), ANSI/AWS D1.2 for aluminum (ANSI/AWS 1989a), and ANSI/AWS D1.3 for sheet metal (ANSI/AWS 1989b). Welding qualifications in accordance with ASME (1989), Section IX, are acceptable. All slag, spatter, and weld discontinuities shall be removed by grinding or by other industry accepted method. All load-bearing welds shall be magnetic particle and/or liquid penetrant weld examined. All weld examinations shall be performed in accordance with ASNT SNT-TC-1A (ASNT 1984).

\subsection{SUPPORT EQUIPMENT}

Support equipment shall be provided with, and mounted onto, the transport system. Support equipment is defined as that equipment which is essential to the overall mission of sludge removal, transport, and final offloading but is not part of the packaging or transporter. Support equipment includes equipment to pump the sludge from the container, operate and monitor loading and offloading operations, obtain samples for laboratory analyses, perform radioactive NDA, mix container contents, vent displaced air during loading and unloading operations, and flush the container and piping following loading and unloading operations. (Specific equipment and service if ife requirements will be identified in a purchase specification.) Support equipment may include, but is not limited to, the following:

- Redundant, sealable, passive, high-efficiency particulate air (HEPA) filtered vents capable of being sealed during transport

- Equipment to sluice the container interior 
WHC-SD-TP-PDC-035 Rev. 0

- A console to monitor and control offloading operations

- Equipment to remove container contents

- Equipment to remove residual sludge heel

- Equipment (that does not breach containment) for neutron detection

- Equipment to mix container contents

- Equipment to monitor the liquid/sludge level to prevent overfilling and to monitor the mass balance during pumpout

- Hose reel and hose to connect to flush water supply

- Equipment as necessary to interface with TWRS-supplied utilities, i.e., electrical power, on and offloading piping, flush water, supplied air, etc.

\subsection{GENERAL REQUIREMENTS}

\subsection{TRANSPORTATION SAFETY}

The SARP shall document that the packaging and transport system meets Hanford Site, Type B, HRCQ, fissile, transportation safety criteria, or other criteria consistent with its application, per WHC-CM-2-14, for the payload defined in Section 2.0 and the normal and accident conditions defined in Sections 5.1.1 and 5.1.2. Environmental data for normal and accident conditions are specified in Section 5.1.6.

The design of the overall packaging and support equipment systems shall take into account the safety of the workers from the perspective of the Hanford Site "Master Safety Rules" referenced in WHC-CM-1-10 and OSHA standards per 29 CFR 1910.

\subsubsection{Normal Conditions}

The package shall be demonstrated to withstand normal onsite transfer conditions either through testing or analysis. Normal shock and vibration associated with truck transport shall be evaluated to ensure that the package maintains containment (leaktight), shielding, and nuclear criticality control under the following conditions: (Note: The package will remain on board the transport trailer during all filling and unloading operations.)

- Environmental Conditions. The design temperature limits for the individual components, parts, and materials of the package shall be determined by analyses and/or testing. The analyses and/or tests shall be based upon the conditions listed in Section 5.1.6. Operational temperatures shall be shown to not exceed the design limits. 
- Maximum heat generation rate of worst-case source from Section 2.2 plus maximum solar heat load (see Table 14) plus maximum air temperature of $46{ }^{\circ} \mathrm{C}\left(115^{\circ} \mathrm{F}\right)$

- Minimum air temperature of $-33^{\circ} \mathrm{C}\left(-27{ }^{\circ} \mathrm{F}\right)$ plus maximum heat generation rate from worst case source in Section 2.2

- Minimum air temperature of $-33^{\circ} \mathrm{C}\left(-27^{\circ} \mathrm{F}\right)$ and zero heat generation rate.

- Reduced External Pressure. An external pressure of $24.0 \mathrm{kPa}$ (3.5 psi) absolute.

- Increased External Pressure. An external pressure of $138 \mathrm{kPa}$ (20 psi) absolute.

- Vibration. The package shall be evaluated per ANSI N14.23 (ANSI 1992) for normal vibration during movement by the selected transport vehicle along the route specified in Section 3.0.

- Water Spray. The package shall be evaluated for a water spray that simulates exposure to rainfall of approximately $5 \mathrm{~cm}$ (2 in.) per hour for at least one hour.

- Penetration. Impact of the hemispherical end of a vertical steel cylinder of 3.2-cm (1.25-in.) diameter and $6-\mathrm{kg}$ (13-ib) mass, dropped from a height of $1 \mathrm{~m}(40 \mathrm{in}$.) onto the exposed surface of the package that is expected to be most vulnerable to puncture. The long axis of the cylinder shall be perpendicular to the package surface.

\subsubsection{Accident Conditions}

For Hanford onsite transportation conditions, accident events are defined for impact, puncture, fire, and crush. The package shall be designed to provide containment, shielding, and criticality control for these conditions over the travel route and distance specified in Section 3.0.

The preliminary risk analysis (Green 1996) determined these design criteria based on package failure threshold.

Based on the preliminary risk evaluation (Green 1996), the following provide the accident safety design criteria. For purposes of onsite package evaluation, these events are assumed to occur nonsequentially. For design evaluation, these accidents shall be evaluated at an ambient temperature between $-33^{\circ} \mathrm{C}\left(-27{ }^{\circ} \mathrm{F}\right)$ and $46{ }^{\circ} \mathrm{C}\left(115^{\circ} \mathrm{F}\right)$, whichever is more severe for the individual incident. The packaging system shall be evaluated carrying the worst-case payload, as described in Section 2.0.

- Impact. Impact failure shall not occur below a change in velocity of $56 \mathrm{~km} / \mathrm{h}(35 \mathrm{mi} / \mathrm{h})$ onto a typical Hanford Site surface. The package shall impact in an orientation expected to cause maximum damage. 
- Puncture. The worst-case credible puncture incident shall provide the equivalent resistance of $7.6 \mathrm{~cm}$ ( 3 in.) of steel or steel equivalent.

- Fire. The packaging shall survive an $802{ }^{\circ} \mathrm{C}\left(1,475{ }^{\circ} \mathrm{F}\right)$ engulfing fire for 15 minutes with no loss of contents in excess of Section 5.1.2.2 criteria. The surface absorptivity of the package shall be the greater of the anticipated absorptivity or 0.8 and shall be assumed to have an emissivity coefficient of 0.9 . The package can be assumed to be actively cooled after the 15 minutes. All containment boundary seals shall remain functional. Steam pressure buildup due to water boiling shall be evaluated and accounted for in the design.

- Crush. The packaging shall survive a 7,258-kg $(16,000-1 b)$ crush force from the trailer, with the force oriented in the direction expected to induce the most damage to the container. If the actual weight of the trailer after fabrication is greater than $7,258 \mathrm{~kg}$ $(16,0007 \mathrm{~b})$, the SARP shall adjust the final risk analysis using the actual trailer weight.

5.1.2.1 Accident Frequency Analysis. The SARP shall document the results of an accident frequency analys is to assess the safety of the packaging and to determine the estimated annual accident release frequency during transfers. If mileage or time restrictions apply, these restrictions shall be identified in the SARP.

5.1.2.2 Dose Consequence Analysis. An evaluation of dose consequences will be performed as required to verify the package meets the criteria of Mercado (1994). A preliminary dose consequence study is included as an attachment to Green (1996).

\subsubsection{Thermal}

Decay heat generation of the sludge shall not preclude the packaging from maintaining its integrity. The SARP shall document the thermal safety analysis and establish a decay heat generation limit. The heat generation is given in Section 2.6.

The maximum accessible surface temperature of the package shal1 not exceed $185^{\circ} \mathrm{F}$ in the shade under the ambient conditions of Table 13.

\subsubsection{Shielding}

A shielding analysis shall be provided in the SARP to ensure that the packaging will meet the following dose rate limits under the normal and accident conditions of Sections 5.1.1 and 5.1.2. 
WHC-SD-TP-PDC-035 Rev. 0

- Shielding shall ensure that radiation levels under normal transport conditions (Section 5.1.1) do not exceed the following:

- $200 \mathrm{mrem} / \mathrm{h}$ at any point on the external surface of the package (See also Section 4.2.8 for an operations-control design limit.)

- $10 \mathrm{mrem} / \mathrm{h}$ at $2 \mathrm{~m}(6.6 \mathrm{ft})$ from the edge of the trailer (exclusive-use 1imit)

- $2 \mathrm{mrem} / \mathrm{h}$ in any normally occupied position of the transport vehicle.

- Shielding shall ensure that radiation levels under credible accident conditions (Section 5.1 .2$)$ do not exceed $1000 \mathrm{mrem} / \mathrm{h} \mathrm{at} 1 \mathrm{~m}(3.3 \mathrm{ft}$ ) from the container if any shielding is dislodged from the accident

\subsubsection{Criticality}

A criticality analysis shall be performed and documented in the SARP using the worst-case payload (Section 2.2) to demonstrate that the payload will remain subcritical ( $k_{\text {eff }}$ shall be less than 0.95 . $k_{\text {eff }}$ is the mean value plus two standard deviations, plus bias) under the following conditions:

- During the normal transport conditions of Section 5.1.1, for three packages, under the most reactive credible configuration consistent with the chemical and physical form of the packaged material with full water reflection

- During and subsequent to the accident conditions of Section 5.1.2, for one package, under the most reactive credible configuration consistent with the chemical form and damaged condition the packaged material, with optimum interspersed aqueous moderation, with ful? water reflection.

\subsubsection{Environmental Data}

Environmental conditions under which the packaging and trailer will operate are found in this section and WHC-SD-TP-RPT-004 (Fadeff 1992).

Ambient air temperatures at the Hanford Site for the peak summer month are shown in Table 13. The maximum solar radiation is shown in Table 14. 
WHC-SD-TP-PDC-035 Rev. 0

Table 13. Peak Hanford Air Temperatures

\begin{tabular}{|c|c|c|c|}
\hline Time & $\begin{array}{c}\text { Temperature } \\
{ }^{\circ} \mathrm{C} /{ }^{\circ} \mathrm{F}\end{array}$ & Time & $\begin{array}{c}\text { Temperature } \\
{ }^{\circ} \mathrm{C} /{ }^{\circ} \mathrm{F}\end{array}$ \\
\hline $12 \mathrm{a} . \mathrm{m}$. & $28 / 82$ & 2 p.m. & $44 / 111$ \\
\hline 2 a.m. & $26 / 78$ & $4 \mathrm{p} . \mathrm{m}$. & $46 / 115$ \\
\hline 4 a.m. & $24 / 75$ & 6 p.m. & $45 / 113$ \\
\hline 6 a.m. & $23 / 74$ & $8 \mathrm{p} . \mathrm{m}$. & $38 / 100$ \\
\hline 8 a.m. & $29 / 85$ & 10 p.m. & $32 / 89$ \\
\hline 10 a.m. & $36 / 97$ & 12 a.m. & $28 / 82$ \\
\hline 12 p.m. & $39 / 103$ & & \\
\hline
\end{tabular}

Table 14. Maximum Solar Radiation $\left(B T U / h-f t^{2}\right)$.

\begin{tabular}{|l|c|c|c|c|c|c|c|c|c|}
\hline \multirow{2}{*}{ Time } & \multicolumn{8}{|c|}{ Vertical surfaces facing } & \multicolumn{1}{c|}{$\begin{array}{c}\text { Horizontal } \\
\text { surface } \\
\text { facing up }\end{array}$} \\
\cline { 2 - 9 } & N & NE & E & SE & s & Sw & W & NW \\
\hline a.m. & 0 & 0 & 0 & 0 & 0 & 0 & 0 & 0 & 0 \\
6 a.m. & 57 & 192 & 211 & 105 & 17 & 17 & 17 & 17 & 64 \\
8 a.m. & 35 & 173 & 268 & 208 & 42 & 32 & 32 & 32 & 127 \\
10 a.m. & 42 & 56 & 177 & 213 & 126 & 45 & 42 & 42 & 281 \\
12 noon & 45 & 45 & 49 & 120 & 167 & 120 & 49 & 45 & 314 \\
2 p.m. & 42 & 42 & 42 & 45 & 126 & 213 & 177 & 56 & 281 \\
4 p.m. & 35 & 32 & 32 & 32 & 42 & 208 & 268 & 173 & 127 \\
6 p.m. & 57 & 17 & 17 & 17 & 17 & 105 & 211 & 192 & 64 \\
8 p.m. & 0 & 0 & 0 & 0 & 0 & 0 & 0 & 0 & 0 \\
\hline
\end{tabular}

\subsubsection{Gas Generation Analysis}

$K$ East Basin sludge and water mixtures shall be evaluated for radiolytic hydrogen gas generation. Shipping time will be specified within the SARP to less than the amount of time that would be required to reach a hydrogen gas concentration of $5 \%$ of the free container volume within a sealed container (if sealed within an oxygen bearing atmosphere). As a bounding case, the container can be assumed to be sealed for a period of five days during the transfer route specified in Section 3.0. A maximum design pressure rating of the packaging shall be established by the container supplier by testing or analysis. The maximum allowable operating pressure limit shall be specified in the SARP.

The SARP shall analyze the effects of gas generation and develop appropriate operational controls, such as transfer time limits, venting through HEPA filters (just prior to transport), inerting the void space, etc. 
WHC-SD-TP-PDC-035 Rev. 0

\subsubsection{Containment}

The packaging shall be designed, constructed, and prepared for shipment so that when subjected to normal conditions, the package contairment boundary shall remain leaktight in accordance with the ANSI N14.5 (ANSI 1.987) definition of "leaktight." If the package design incorporates a venting feature, the leakage rate evaluation shall be made with the vent(s) sealed.

The packaging shall be designed, constructed, and prepared for shipment so that when subjected to accident conditions, the criteria of section 5.1.2.2 are met.

\subsection{ALARA}

The packaging and transport system are to be designed to minimize radiation and hazardous material exposure to operating personnel and shall be consistent with the requirements of WHC-IP-1043 (Berglund 1995).

\subsection{TRANSPORTATION SAFETY CLASS}

The transportation safety class of the packaging and transport system has been determined by a transportation safety class analysis presented in Appendix B. This analysis assumed the total failure of the packaging system and the release of all of its contents to the environment at the worst possible location on the transportation route. An airborne release fraction was then applied to the material at risk to determine the airborne quantity. For the shipment of the $K$ Basin sludge, the worst-case release location is within the $100 \mathrm{~K}$ Area, just outside the basins.

The results of the transportation safety class analysis are documented in Nelson (1996), attached as Appendix B. The analysis concludes that at least one "safety class" (formerly described as "Safety Class 1" per W'HC-CM-4-46, Nonreactor Facility Safety Analysis Manual) barrier is required for shipping a package containing $K$ East Basin sludge.

\subsection{MAINTENANCE, TOOLING, AND SPARES}

Ease and minimization of maintenance shall be designed into the transport system. Special tools, vendor spare parts, and maintenance data to operate, replace, or repair the system shall be provided.

\subsection{QUALITY ASSURANCE}

Controls shall be established for the design, fabrication, inspection, and testing of the packaging and transportation system and shail be in accordance with WHC-CM-4-2 and WHC-IP-0705 (1995). 


$$
\text { WHC-SD-TP-PDC-035 Rev. } 0
$$

\subsection{REFERENCES}

10 CFR 71, 1994, "Packaging and Transportation of Radioactive Material," Parts 71.71 "Normal Conditions of Transport", and Table A-1 effective Apri] 1996, and 71.37 and Subpart H, "Quality Assurance, " Code of Federal Regulations, as amended.

29 CFR 1910, 1994, "Occupational Safety and Health Standards," Code of Federal Regulations, as amended.

49 CFR 172, 1994, "Transportation," Subpart F, "Placarding," Code of Federal Regulations, as amended.

49 CFR 393, 1994, "Protection Against Shifting or Falling Cargo," Subpart I, Code of Federal Regulations, as amended.

Alderman, C. J., 1995, Westinghouse Hanford Company Recommended Strategy for $K$ Basin S7udge Disposition, WHC-SD-SNF-SP-001, Rev. 0, Westinghouse Hanford Company, Richland, Washington.

ANSI, 1992, Draft American National Standard Design Basis for Resistance to Shock and Vibration of Radioactive Material Packages Greater Than One Ton in Truck Transport, ANSI N14.23, American National Standards Institute, New York, New York.

ANSI, 1987, Radioactive Materials Leakage Tests on Packages for Shipment, ANSI N14.5-1987, American National Standards Institute, New York. New York.

ANSI/AWS, 1989a, Structura7 We7ding Code--A7uminum, ANSI/AWS D1.2, American National Standards Institute and American Welding Society, Miami, Florida.

ANSI/AWS, 1989b, Structura7 We7ding Code--Sheet Meta7, ANSI/AWS 01.3, American National Standards Institute and American Welding Society, Miami, Florida.

ANSI/AWS, 1989c, Structura7 Welding Code--Steel, ANSI/AWS D1.1, American National Standards Institute and American Welding Society, Miami, Florida.

ASME, 1992, Section VIII, "Rules for Construction of Pressure Vessels," Division 1 ASME Boiler and Pressure Vessel Code, American Suciety of Mechanical Engineers, New York, New York.

ASME, 1989, Section IX, "Qualification Standard for Welding and Brazing Procedures, Welders, Brazers, and Welding and Brazing Operators, "ASME Boiler and Pressure Vessel Code, American Society of Mechanical Engineers, New York, New York.

ASNT, 1984, Recommended Practice, SNT-TC-1A, American Society for Nondestructive Testing, Columbus, Ohio. 
WHC-SD-TP-PDC-035 Rev. 0

Berglund, 0. D., 1995, WHC Occupational ALARA Program, WHC-IP-1043, Rev. 0, Westinghouse Hanford Company, Richland, Washington.

Bergsman, K. H., 1996, Spent Nuclear Fuel Project Dose Management P7an, WHCSD-SNF-SP-010, Rev. 0, Westinghouse Hanford Company, Richland, Washington.

Brisbin, S. A., 1995a, Data for Preparation of the $K$ Basin Sludge Packaging Design Criteria (internal memo SAB-95-007 to T. A. Tomaszewski, December 8), Westinghouse Hanford Company, Richland, Washington.

Brisbin, S. A., 1995b, Recommended Transport System for K Basin Sludge Transfer to the Tank Waste Remediation System, WHC-SD-SNF-PD-010, Rev. 0, Westinghouse Hanford Company, Richland, Washington.

Fadeff, J. G., 1992, Environmental Conditions for On-Site Hazardous Materials Packages, WHC-SD-TP-RPT-004, Rev. 0, Westinghouse Hanford Company, Richland, Washington.

Green, J. R., 1996, Preliminary Radiological Risk Assessment for Risk-Based Design Criteria of the $K$ Basin Sludge Package, WHC-SD-TP-RA-002, Rev. 0 , Westinghouse Hanford Company, Richland, Washington.

HSRCM-1, Hanford Site Radiological Control Manual, Pacific Northwest National Laboratory, Richland, Washington.

IAEA, 1990, Advisory Material for the IAEA Regulations for the Safe Transport of Radioactive Material, 3rd Edition, International Atomic Energy Agency, Vienna, Austria.

Mercado, J. E., 1994, Report on Equivalent Safety for Transportation and Packaging of Radioactive Materials, WHC-SD-TP-RPT-001, Rev. 0 , Westinghouse Hanford Company, Richland, Washington.

$\mathrm{Ne}$ lson, J. V., 1996, Transportation Safety Class Analysis (internal memo 8M730-JVN-96-004 to J. R. Green, January 19), Westinghouse Hanford Company, Richland, Washington.

Precechte1, D. R., 1995, Parametric Study on S7udge Transportation Cost as a Function of Source Term (internal memo DRP-95-001 to M. J. Wiemers, September 12), Westinghouse Hanford Company, Richland, Washington.

Schwarz, R. A., 1992, New Origen2 Runs for N-Reactor Fuel (internal memo to K. H. Bergsman, February 25), Westinghouse Hanford Company, Richland, Washington.

Short, S. M., 1995, Spent Nuclear Fuel Project Technical Databook, WHC-SD-SNF-TI-015, Rev. 0, Westinghouse Hanford Company, Richland, Washington.

Tomaszewski, T. A., 1995, Workplan for $K$ Basin S7udge Transportation (Packaging Engineering internal document TR-96-003-19, October 25), Westinghouse Hanford Company, Richland, Washington. 
WHC-CM-1-10, Safety Manual, Westinghouse Hanford Company, Richland, Washington.

WHC-CM-2-14, Hazardous Material Packaging and Shipping, Westinghouse Hanford Company, Richland, Washington.

WHC-CM-4-2, Quality Assurance Manual, Westinghouse Hanford Company, Richland, Washington.

WHC-CM-4-29, Nuclear Criticality Safety Manual, Westinghouse Hanford Company, Richland, Washington.

WHC-CM-4-46, Nonreactor Facility Safety Analysis Manual, Westinghouse Hanford Company, Richland, Washington.

WHC-IP-0705, Quality Assurance Program Plan for the Hazardous Materials Transportation and Packaging Program, Westinghouse Hanford Company, Richland, Washington. 


\section{WHC-SD-TP-PDC-035 Rev. 0 \\ APPENDIX A \\ ORIGEN2 INPUT FILES FOR TOTAL SOURCE AND WORST SOURCE}

The following is the Origen2 input file that was used to calculate the total source additional actinides included in Table 6 of the packaging design criteria.

\section{Origen2 Input File for Total Source}

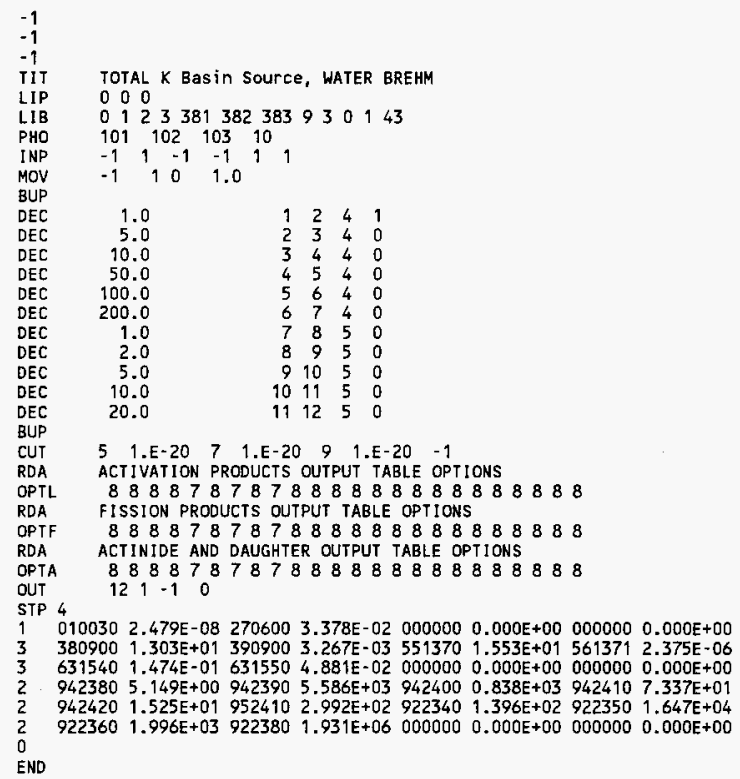


The following is the Origen 2 input file that was used to calculate the worst source additional actinides included in Table 7 of the packaging design criteria.

\section{Origen2 Input File for Worst Source}

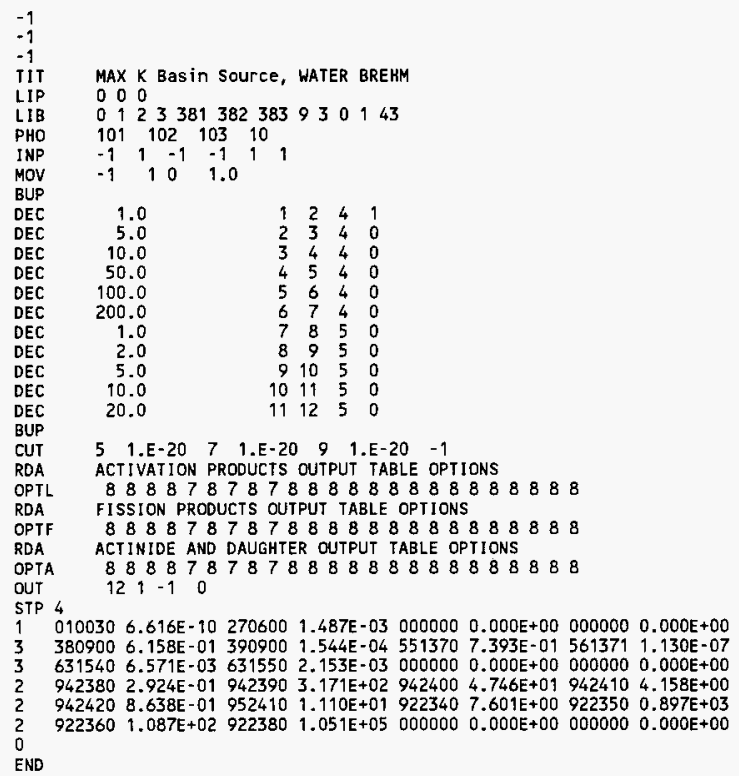


WHC-SD-TP-PDC-035 Rev. 0

\section{APPENDIX B} TRANSPORTATION SAFETY CLASS ANALYSIS FOR
SHIPMENT OF SLUDGE FROM K EAST BASIN

Westinghouse
Hanford Company

From: Nuclear Physics and Shielding

Phone: $\quad 376-4480$ HO-35

Date: January 19, 1996

SUbject: TRANSPORTATION SAFETY CLASS ANALYSIS FOR SHIPMENT OF SLUDGE FROM $K$ EAST BASIN

To:

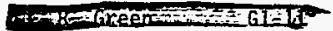

cc:

J. G. Field

G1-11

J. Greenbors

HO- 35

A. L. Ramb] e

A3-38
Internal

Memo

8M730-JVN-96-004

References: See Attachment 1 .

\section{Introduction}

The $K$ East Basin is used for under water storage of irradiated fuel from Hanford production reactors. During its lifetime of four decades, up to 68 cubic meters of radioactive particulate matter has settled to the bottom of the basin as sludge. Plans are to remove this sludge, transport it to the 200 East Area, and store it there in double-shell tanks. Shipment payloads will consist of sludge, plus basin and process water.

This report provides a safety class analysis for the shipment of the sludge and contaminated water from the $K$ East Basin.

\section{Source Term}

The source term in this analysis is divided into two classes: radioactive sludge and contaminated water from the basin. In quantifying the source term in section 2 of the $K$ East Bas in Sludge PDC), it was assumed that each shipment will consist of 30 percent sludge and 70 percent water by volume. The worst-case source terms for the sludge, water, and their sum are listed in Tables 1. Curie inventories in the sludge were specified by radionuclide as May 1993 values. The radionuclide activities in the sludge that are listed in Table 1 have been decayed two years and ejght months (to January 1996 levels) using the Microshield program (Ref. 1). Activities in the water were specified as 1995 values. These data were not decay corrected, and thus, the radionuclide inventories listed in Table 1 for the water were taken directiy from section 2 of the PDC.

The tota? activity of the sludge source in Table $\mathrm{l}$ is $730 \mathrm{Ci}\left(2.7 \times 10^{13} \mathrm{~Bq}\right)$. The total activity of the contaminated water is over three orders of magnitude less at $0.18 \mathrm{Ci}\left(6.6 \times 10^{\circ} \mathrm{BQ}\right)$. As will be discussed later, the water source term is insignificant in comparison with the sludge source term. 
Page 2

January 19, 1996

\begin{tabular}{|c|c|c|c|}
\hline \multirow{2}{*}{ Radionuclide } & \multicolumn{3}{|c|}{ Radionuclide Inventory (curies) } \\
\hline & Sludge & Water & Total \\
\hline${ }^{3} \mathrm{H}$ & & $6.4 \times 10^{-6}$ & $6.4 \times 10^{-6}$ \\
\hline${ }^{60} \mathrm{Co}$ & $1.2 \times 10^{0}$ & & $1.2 \times 10^{0}$ \\
\hline${ }^{90} \mathrm{Sr}$ & $7.9 \times 10^{1}$ & $3.5 \times 10^{-2}$ & $7.9 \times 10^{1}$ \\
\hline${ }^{90} \mathrm{Y}$ & $7.9 \times 10^{1}$ & $3.5 \times 10^{-2}$ & $7.9 \times 10^{1}$ \\
\hline${ }^{137} \mathrm{Cs}$ & $6.0 \times 10^{1}$ & $5.5 \times 10^{-2}$ & $6.0 \times 10^{1}$ \\
\hline${ }^{i 37 m} \mathrm{Ba}$ & $5.7 \times 10^{1}$ & $5.5 \times 10^{-2}$ & $5.7 \times 10^{1}$ \\
\hline${ }^{154} \mathrm{Eu}$ & $1.4 \times 10^{\circ}$ & & $1.4 \times 10^{0}$ \\
\hline${ }^{155} \mathrm{Eu}$ & $6.9 \times 10^{-1}$ & & $6.9 \times 10^{-1}$ \\
\hline${ }^{231} \mathrm{Th}$ & $1.9 \times 10^{-3}$ & & $1.9 \times 10^{-3}$ \\
\hline${ }^{234} \mathrm{Th}$ & $3.5 \times 10^{-2}$ & & $3.5 \times 10^{-2}$ \\
\hline${ }^{233} \mathrm{~Pa}$ & $3.2 \times 10^{-5}$ & & $3.2 \times 10^{-5}$ \\
\hline${ }^{234} \mathrm{~Pa}$ & $5.7 \times 10^{-5}$ & & $5.7 \times 10^{-5}$ \\
\hline${ }^{234 \mathrm{~m}} \mathrm{~Pa}$ & $3.5 \times 10^{-2}$ & & $3.5 \times 10^{-2}$ \\
\hline${ }^{234} \mathrm{U}$ & $4.8 \times 10^{-2}$ & $5.2 \times 10^{-7}$ & $4.8 \times 10^{-2}$ \\
\hline${ }^{235} \mathrm{U}$ & $1.9 \times 10^{-3}$ & $2.1 \times 10^{-8}$ & $1.9 \times 10^{-3}$ \\
\hline${ }^{235} \mathrm{U}$ & $7.0 \times 10^{-3}$ & $7.7 \times 10^{-8}$ & $7.0 \times 10^{-3}$ \\
\hline${ }^{238} \mathrm{U}$ & $3.5 \times 10^{-2}$ & $3.9 \times 10^{-7}$ & $3.5 \times 10^{-2}$ \\
\hline${ }^{238} \mathrm{Pu}$ & $4.9 \times 10^{0}$ & $4.2 \times 10^{-5}$ & $4.9 \times 10^{0}$ \\
\hline${ }^{239} \mathrm{Pu}$ & $2.0 \times 10^{9}$ & $1.9 \times 10^{-4}$ & $2.0 \times 10^{1}$ \\
\hline${ }^{240} \mathrm{Pu}$ & $1.1 \times 10^{9}$ & $1.9 \times 10^{-4}$ & $1.1 \times 10^{1}$ \\
\hline${ }^{241} \mathrm{Pu}$ & $3.8 \times 10^{2}$ & & $3.8 \times 10^{2}$ \\
\hline${ }^{242} \mathrm{Pu}$ & $3.3 \times 10^{-3}$ & & $3.3 \times 10^{-3}$ \\
\hline${ }^{241} \mathrm{Am}$ & $4.0 \times 10^{1}$ & $8.7 \times 10^{-4}$ & $4.0 \times 10^{1}$ \\
\hline Total & $7.3 \times 10^{2}$ & $1.8 \times 10^{-1}$ & $7.3 \times 10^{2}$ \\
\hline
\end{tabular}

a sludge source was decayed to January 1996 from the Mey 1993 values in section 2 of the PDC.

$b$ Activities of radionuelides in the water source were taken directly from section 2 of she POC. These data were based on 1994 and 1995 assessments. 


\section{Discussion and Results}

As outlined in Reference 2, the event considered is an unmitigated release, which has been interpreted as release of $100 \%$ of the source from any packaging. The doses to be calculated are the Committed Effective Dose Equivalent (CEDE) to the maximally exposed offsite and onsite individuals with only inhalation and external exposure considered. The onsite individual is assumed to be located $100 \mathrm{~m}$ away from the release, while the offsite individual is assumed to be located at the site boundary. Since an offsite receptor could be a boater in the Columbia River, the near bank of the river was considered as part of the boundary. The point of release was assumed to be near the $K$ East Basin because of its proximity to the site boundary (the Columbia River).

The computer code GXQ (Ref. 3) was used to calculate atmospheric dispersion coefficients $(\Psi / Q)$ for a comprehensive set of distances and directions from the assumed release point to the site boundary, and for a distance of $100 \mathrm{~m}$ from the release point in all directions. The input file for this $G \times Q$ run is Tisted in Attachment 2. Meteorological data used were the 1983 to 1991 averages by area. The largest $\Psi / Q$ values that were not exceeded more than $0.5 \%$ of the time were selected for further use in this analysis.

The computer code GENII (Ref. 4) was then used to calculate the dose to the affected individua?s. The input file for the GENII run is listed in Attachment 3 . For assessment of the safety class, only the inhalation and direct radiation pathways for the maximally exposed members of the population are considered. The following i ibraries were accessed:

GENII Default Parameter Values (28-Mar-90 RAP)

Radionuclide Library - Times<100 years (23-July-93 PDR)

External Dose Factors for GENII in person Sv/yr per Bq/n (8-May-90 RAP)

Horst-Case Solubilities, Yearly Dose Increments (23-jul-93 PDR).

Jofu Mishima, in his study of release fractions (Ref. 5), has a bounding airborne release fraction (ARF) of $5.0 \times 10^{-5}$ for the free-fall spill of slurries from a height of $3 \mathrm{~m}$. The corresponding respirable fraction (RF) is 0.8 . The ARFXRF value of $4.0 \times 10^{-5}$ was applied to the doses computed by GENII for the sludge source.

Appropriate ARF and RF bounding values for the contaminated water are $2.0 \times 10^{-4}$ and 0.5 , which are given in Reference 5 for the free-fall spill of aqueous solutions from a height of $3 \mathrm{~m}$. The ARFXRF value $\left(1.0 \times 10^{-4}\right)$ for the aqueous solutions is a factor of 2.5 times higher than the corresponding value for slurries. However, with the exception of tritium, the quantity of each radionuclide in the water is more than three orders of magnitude less than in the sludge, and the amount of tritium in the water is insignificant compared to the curie inventory in the sludge. Consequently, a GENII calculation of the negligible doses from the contaminated water was not done.

In the worst case scenario, the hypothesized spill would result in a drop of less than three meters. However, Reference 5 provides bounding values for only a three-meter drop. Thus, the conservative three-meter data were used. 
J. R. Green

8M730-JVN-96-004

Page 4

January 19,1996

As indicated above, the product of the ARF and RF values for slurries $\left(4.0 \times 10^{-5}\right)$ was applied to the results of the GENII run, which was made for the entire sludge source term. The GENII results were also multiplied by appropriate $\Psi / Q$ values from $G X Q$. The highest $\Psi / Q$ value for an offsite receptor is $1.8 \times 10^{-3} \mathrm{sec} / \mathrm{m}^{3}$ at a location on the near bank of the Columbia River, $790 \mathrm{~m}$ west of the postulated accident site at the $K$ East Basin. The highest $\Psi / Q$ value for an onsite receptor $100 \mathrm{~m}$ from the accident site is 7.3 $\times 10^{-2} \mathrm{sec} / \mathrm{m}^{3}$.

The committed effective doses, formerly named the committed effective dose equivalent (CEDE), from the siudge source term are tabulated in Table 2. These are 50-year committed doses. The maximally exposed organ is the bone surfaces from inhalation of ${ }^{241} \mathrm{Am}$. The data in Table 2 are inhalation doses onty, because they dominate the doses from direct radiation. The doses from the contaminated water are also insignificant by comparison, as previously discussed.

The offsite CEDE, 0.0085 SV $(0.85 \mathrm{rem})$, is less than $25 \mathrm{rem}$, but greater

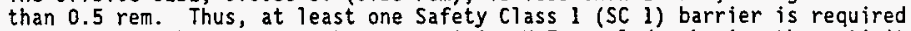
(Ref. 2) for shipping a package containing $K$ East sludge having the activity given in Table 1.

\begin{tabular}{|c|c|c|}
\hline \multicolumn{2}{|c|}{ Table. 2. Transportation Safety Class Analysis Doses } \\
\hline Individual & CEDE, SV (rem) & Organ, Sv (rem) \\
\hline Onsite & $3.5 \times 10^{-1}\left(3.5 \times 10^{-1}\right)$ & $6.4 \times 10^{0}\left(6.4 \times 10^{2}\right)$ \\
\hline Offsite & $8.5 \times 10^{-3}\left(8.5 \times 10^{-1}\right)$ & $1.6 \times 10^{-1}\left(1.6 \times 10^{1}\right)$ \\
\hline
\end{tabular}

* The controlling organ is the bone surfoces from ${ }^{241}$ Am inhalation.

Q. Pelsen

J. V. Nelson, Principal Scientist Nuclear Physics and Shielding

$11 p$

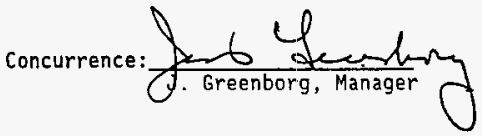

Attachments 6 
WHC-SD-TP-PDC-035 Rev. 0

8M730-JVN-96-004

ATTACHMENT 1

Page 1 of 1

\section{REFERENCES}

1. Microshield 3 Manual, Grove Engineering, Inc., April 1988.

2. Westinghouse Hanford Company Standard Engineering Practices Manual, WHC-CM-6-1, Safety Classification Section, EP-1.4, Rev. 1, December 1991.

3. B. E. Hey, GXQ 4.0 Users' Guide, WHC-SD-GN-SWD-30002, Rev. 1, December 1994.

4. B. A. Napier, D. 1. Strenge, R. A. Peloquin and J. V. Ramsdell, GENII The Hanford Environmenta] Dosimetry Sof tware System, PNL-6584, November 1988.

5. J. Mishima, Airborne Release Fractions/Rates and Respirable Fractions for Nonreactor Nuclear Facilities, DOE-HDBK-3010-94, U. S. Department of Energy, December 1994. 
WHC-SD-TP-PDC-035 Rev. 0

8N730-JVN-96-004

ATTACHMENT 2

Page 1 of 2

\section{GXQ Input File}

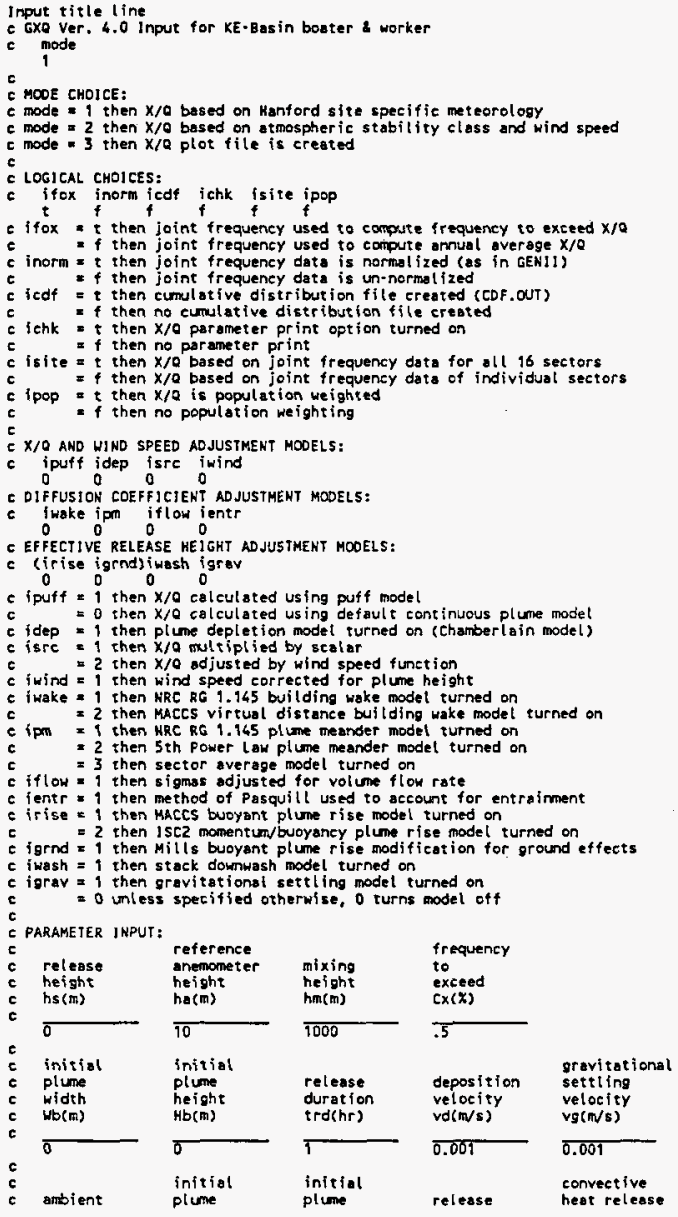




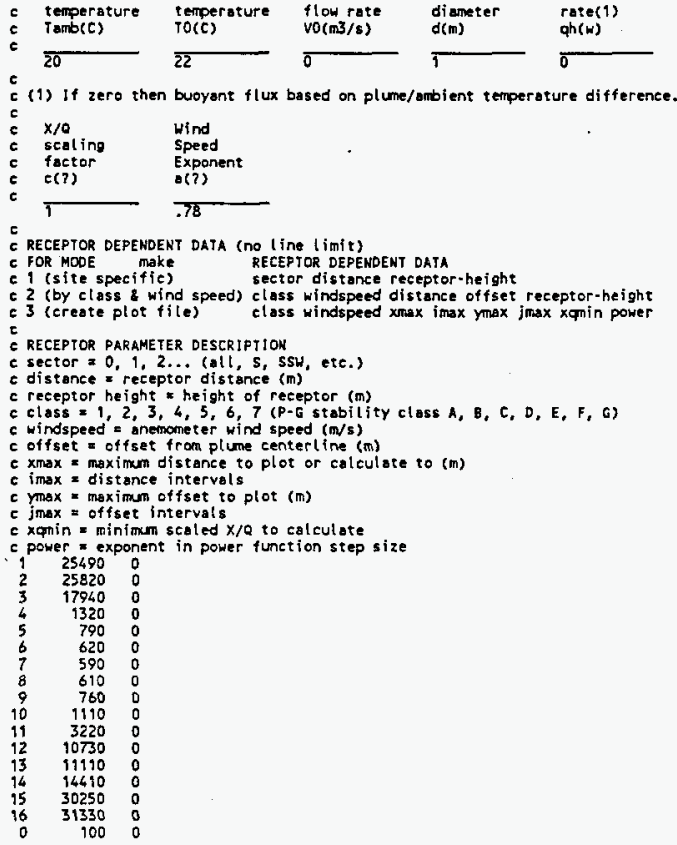




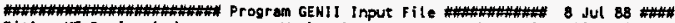
Title: KE Basin sludge source - Worker/Boater - Report by rodionuclide is lGENIIIKbsnsl W3. in Created on $01.05-9995$ at 10:55

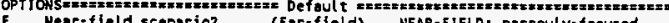

Fear-field scenarior (Far-field) NEAR-F1ELO: narrowly-focused
Population dose? Population dose? (Individual)
(Chronic) Acute retease?
Average Individual dat set used Complete TRANSPORT OPTIONS=Esenenetea Section

T Afr Transport 1 F Finfte pl ume, external

F Biotic Transport (near-field) 3,4 F Ground, external

F Waste Form Degradstion (near) 3,4 F Recreation, external REPORI OPTIONS=\#= $f$ Report AEDE only

T Report by radionuelide

f Reporz by exposure pathway

FAR-FIELD: wide-scale release, multiple sites

f Report by exposure path
f Debug report on screen

I Intalation uptake

F Drinking water ingestion

$F$ Aquatic foods ingestion

F Animal product ingestion

INVENTORY W

4 Inventory input activity units: (1-pCi 2-uti 3.mCi 4-Ci 5-Bq)

o Surface soil source units $(1-\mathrm{m} 2$ 2- $\mathrm{m} 3-3-\mathrm{kg})$

Equilibrium question goes here

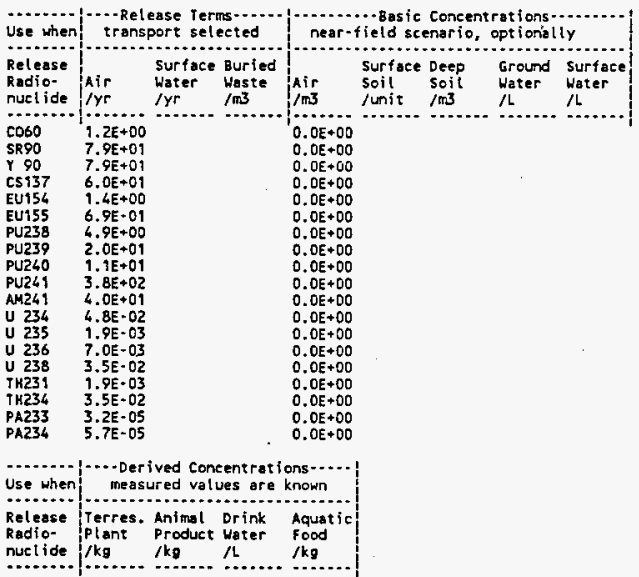

TIME W W

1 Intake ends after (yr)

50 Dose calc. ends after (yr)

0 Release ends of ter (yr)

0 No. of yeers of tir deposition prior to the intake period

- No. of years of irrigotion water deposition prior to the intake period

FAR-FIELD SCENARIOS (IF POPULATION DOSE) 
0 Definition option: 1-Use population grid in fite POP. IN

2-Use total entered on this line

NEAR-FIELD SCENARIOS W

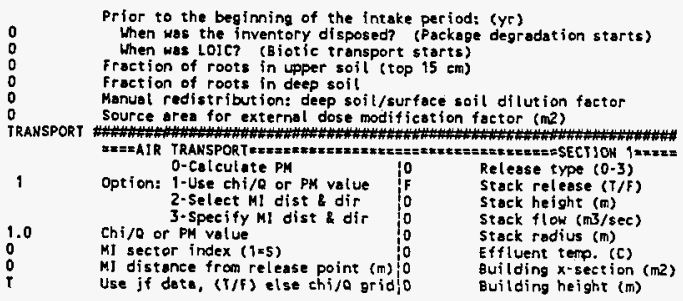

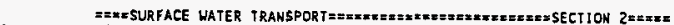

Mixing rat fo model: 0 -use value, 1.river, 2-lake

Mixing ratio, dimensionless

Average river flow rate for: MIXFLG=0(m3/s), MIXFLG=1,2(m/s),

Transit time to irrigation withdrawl location (hr)

if mixing ratio model $>Q$ :

Rate of effluent discharge to receiving water body $(\mathrm{m} 3 / \mathrm{s})$

Longshore distance from release point to usage location (m)

offshore distance to the water intake (m)

Average water depth in surface water body $(m)$

Average river width (m), KixfLG=1 only
Depth of effluent discharge point to surface water (m), lake onty

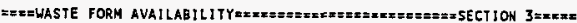
Waste form/package halt life, (yr)

Waste thickness, (m)

Depth of soil overburden, in

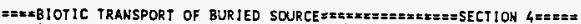
Consider during inventory decay/buildup period (T/F)?

consider during intake period (T/F)? | T-Arid non agricultural

Pre-Intake site condition............. 2-Humid non agricultural

3-Agricultural

EXPOSURE W W W W

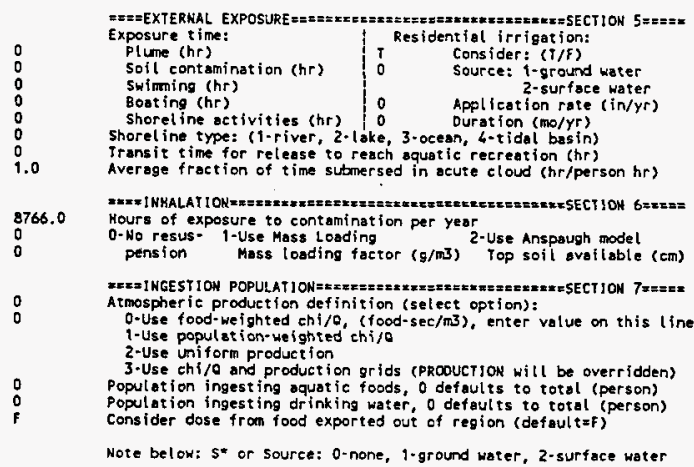


3-Derfved concentration entered sbove

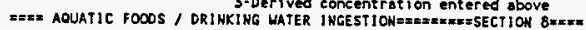
Salt water? (defoult is fresh)

\begin{tabular}{|c|c|c|c|c|c|c|c|}
\hline $\begin{array}{l}\text { USE } \\
? \\
\text { T/F } \\
\ldots\end{array}$ & $\begin{array}{l}\text { FOOD } \\
\text { TYPE } \\
. . .\end{array}$ & $\begin{array}{l}\text { TRAN= } \\
\$ 1 \mathrm{~T} \\
\mathrm{hr} \\
-. . .\end{array}$ & $\begin{array}{l}\text { PROS } \\
\text { UCTIOH } \\
\mathrm{kg} / \mathrm{Yr}\end{array}$ & $\begin{array}{l}\text { - CONSUM } \\
\text { HOLOUP } \\
\text { da }\end{array}$ & $\begin{array}{l}\text { PTION- } \\
\text { RATE } \\
\text { kg/Yr }\end{array}$ & & RINKING WATER \\
\hline $\mathbf{F}$ & $\begin{array}{l}\text { FISH } \\
\text { MOLLUS }\end{array}$ & $\begin{array}{l}0.00 \\
0.00\end{array}$ & $\begin{array}{l}0.0 E+00 \\
0.0 E+00\end{array}$ & $\begin{array}{l}0.00 \\
0.00\end{array}$ & $\begin{array}{l}0.0 \\
0.0\end{array}$ & O & $\begin{array}{l}\text { Source (see above) } \\
\text { Treatment? T/F }\end{array}$ \\
\hline F & $\begin{array}{l}\text { CRUSTA } \\
\text { PLANTS }\end{array}$ & $\begin{array}{l}0.00 \\
0.00\end{array}$ & $\begin{array}{l}0.0 E+00 \\
0.0 E+0 D\end{array}$ & $\begin{array}{l}0.00 \\
0.00\end{array}$ & $\begin{array}{l}0.0 \\
0.0\end{array}$ & 0 & $\begin{array}{l}\text { Holdup/transit (da) } \\
\text { Consumption (L/yr) }\end{array}$ \\
\hline
\end{tabular}

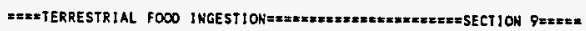

\begin{tabular}{|c|c|c|c|c|c|c|c|c|}
\hline $\begin{array}{l}\text { USE } \\
? \\
T / F\end{array}$ & $\begin{array}{l}\text { F0OD } \\
\text { TYPE }\end{array}$ & $\begin{array}{l}\text { GROW } \\
\text { IIME } \\
\text { da }\end{array}$ & $\begin{array}{l}\text { - IRRIG } \\
\text { S RATE } \\
\text { in/Yr }\end{array}$ & $\begin{array}{l}\text { TION-: } \\
\text { TIME } \\
\text { mo/yr }\end{array}$ & $\begin{array}{l}\text { YJELD } \\
\mathrm{kg} / \mathrm{m} 2\end{array}$ & $\begin{array}{l}\text { PROO. } \\
\text { UCTIION } \\
\text { kg/Yr }\end{array}$ & $\begin{array}{l}- \text { CONSU } \\
\text { HoLDUP } \\
\text { da }\end{array}$ & $\begin{array}{l}\text { APTIOH- } \\
\text { RATE } \\
\text { kg/Yr }\end{array}$ \\
\hline $\begin{array}{l}F \\
F \\
F\end{array}$ & $\begin{array}{l}\text { LEAF V } \\
\text { ROOT V } \\
\text { FRUIT } \\
\text { GRAIN }\end{array}$ & $\begin{array}{l}0.00 \\
0.00 \\
0.00 \\
0.00\end{array}$ & $\begin{array}{ll}0 & 0.0 \\
0 & 0.0 \\
0 & 0.0 \\
0 & 0.0\end{array}$ & $\begin{array}{l}0.0 \\
0.0 \\
0.0 \\
0.0\end{array}$ & $\begin{array}{l}0.0 \\
0.0 \\
0.0 \\
0.0\end{array}$ & $\begin{array}{l}0.0 E+00 \\
0.0 E+00 \\
0.0 E+00 \\
0.0 E+00\end{array}$ & $\begin{array}{l}0.0 \\
0.0 \\
0.0 \\
0.0\end{array}$ & $\begin{array}{l}0.0 \\
0.0 \\
0.0 \\
0.0\end{array}$ \\
\hline
\end{tabular}

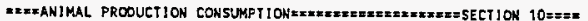

\begin{tabular}{|c|c|c|c|c|c|c|c|c|c|c|c|}
\hline \multirow{3}{*}{\begin{tabular}{l} 
USE \\
$?$ \\
T/F \\
\hdashline \\
$F$ \\
$F$ \\
$F$ \\
$F$
\end{tabular}} & \multirow[b]{2}{*}{$\begin{array}{l}\text { FOOD } \\
\text { TYPE }\end{array}$} & \multicolumn{2}{|c|}{$\begin{array}{l}\cdots \text { HUMAN } \cdots \\
\text { CONSUMPI IOH }\end{array}$} & \multirow{2}{*}{$\begin{array}{l}\text { TOTAL } \\
\text { PROO- } \\
\text { UETION } \\
\mathrm{kg} / \mathrm{YT}\end{array}$} & \multirow{2}{*}{$\begin{array}{l}\text { DRJWK } \\
\text { UAIER } \\
\text { CONTAM } \\
\text { FRACT. }\end{array}$} & \multicolumn{3}{|c|}{ - } & \multicolumn{3}{|c|}{ FEED $=\ldots$} \\
\hline & & $\begin{array}{l}\text { CONSUH } \\
\text { RATE } \\
\text { Kg/Yr }\end{array}$ & $\begin{array}{l}\text { IPI IOW } \\
\text { HOLDUP } \\
\text { da }\end{array}$ & & & $\begin{array}{l}\text { DIET } \\
\text { FRAC- } \\
\text { TIOH }\end{array}$ & $\begin{array}{c}\text { GROW } \\
\text { TIME } \\
\text { da }\end{array}$ & $\begin{array}{l}\text {-IRRIGA } \\
\text { S RAIE } \\
\text { - in/Yr }\end{array}$ & $\begin{array}{l}\text { TION-- } \\
\text { TIME } \\
\text { MO/YT }\end{array}$ & $\begin{array}{l}\text { YIELD } \\
\mathrm{kg} / \mathrm{m3}\end{array}$ & $\begin{array}{l}\text { STOR- } \\
\text { AGE } \\
\text { da }\end{array}$ \\
\hline & $\begin{array}{l}\text { BEEF } \\
\text { POULTR } \\
\text { MILK } \\
\text { EGG }\end{array}$ & $\begin{array}{l}0.0 \\
0.0 \\
0.0 \\
0.0\end{array}$ & $\begin{array}{l}0.0 \\
0.0 \\
0.0 \\
0.0\end{array}$ & $\begin{array}{l}0.00 \\
0.00 \\
0.00 \\
0.00\end{array}$ & $\begin{array}{l}0.00 \\
0.00 \\
0.00 \\
0.00\end{array}$ & $\begin{array}{l}0.00 \\
0.00 \\
0.00 \\
0.00\end{array}$ & $\begin{array}{l}0.0 \\
0.0 \\
0.0 \\
0.0\end{array}$ & $\begin{array}{l}0.0 \\
0.0 \\
0.0 \\
0.0\end{array}$ & $\begin{array}{l}0.00 \\
0.00 \\
0.00 \\
0.00\end{array}$ & $\begin{array}{l}0.00 \\
0.00 \\
0.00 \\
0.00\end{array}$ & $\begin{array}{l}0.0 \\
0.0 \\
0.0 \\
0.0\end{array}$ \\
\hline & $\begin{array}{l}\text { BEEF } \\
\text { MILX }\end{array}$ & & & & & $\begin{array}{l}0.00 \\
0.00\end{array}$ & $\begin{array}{l}0.0 \\
0.0\end{array}$ & $\begin{array}{l}0.0 \\
0.0\end{array}$ & $\begin{array}{l}\text { FORAGE } \\
0.00 \\
0.00\end{array}$ & $\begin{array}{l}0.00 \\
0.00\end{array}$ & $\begin{array}{l}0.0 \\
0.0\end{array}$ \\
\hline
\end{tabular}

W 


\section{CHECKLIST FOR INDEPENDENT TECHNICAL REVIEW}

DOCUMENT REVIEWED

NUMBER: $8 M 730-J V N-96-004$

TITLE: IRANSPORTATION SAFETY CLASS ANALYSIS FOR SHIPMENT OF SLUDGE FROM K EAST BASIN

Reviewer(s): D. E. Lessor

\section{Method(s) of Review}

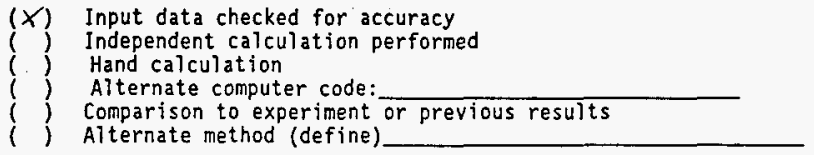

II. Checklist (either check or enter NA if not applied)

(NA) Task completely defined

(WA) Activity consistent with task specification

(WA) Necessary assumptions explicitly stated and supported

(NA) Resources properly identified and referenced

(WA) Resource documentation appropriate for this application

(x) Input data explicitly stated

$(X)$ Input data verified to be consistent with original source

(WA) Geometric mode? adequate representation of actual geometry

(NA) Material properties appropriate and reasonable

(WA) Mathematical derivations checked including dimensional consistency

(X) Hand calculations checked for errors

(NA) Assumptions explicitly stated and justified

(NA) Computer software appropriate for task and used within range of validity

(NA) Use of resource outside range of established validity is justified

(X) Software runstreams correct and consistent with results

(x) Software output consistent with input

(NA) Results consistent with applicable previous experimental or analytical findings

(NA) Resuits and conclusions address all points and are consistent with task requirements and/or established iimits or criteria

(NA) Conclusions consistent with analytical results and established limits

(NA) Uncertainty assessment appropriate and reasonable

() Other (define)

III. Comments:

IV.

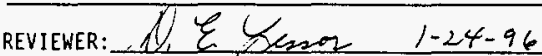




\section{CHECKLIST FOR INDEPENDENT TECHNICAL REVIEY}

\section{DOCUMENT REVIEWED}

NUMBER: 8M730-JVN-96-004

TITLE: TRANSPORTATION SAFETY CLASS ANALYSIS FOR SHIPMENT OF SLUDGE FROM K

$$
\text { EAST BASIN }
$$

Reviewer(s): P. D. Rittmann

I. Method(s) of Review

(X) Input data checked for accuracy

(X) Independent calculation performed

(x) Hand calculation

(†) Alternate computer code:

( Comparison to experiment or previous results

() Alternate method (define)

II. Checklist (either check or enter NA if not applied)
( 7 Task compietely defined
(4) Activity consistent with task specification
( I) Necessary assumptions explicitly stated and supported
( ) Resources properly identified and referenced
(I) Resource documentation appropriate for this application
(广) Input data explicitly. stated
(T Input data verified to be consistent with original source
(4) Geometric model adequate representation of actual geometry
( $)$ Material properties appropriate and reasonable
(wa) Mathematical derivations checked including dimensional consistency
( $)$ Hand calculations checked for errors
( ) Assumptions explicitiy stated and justified
$\rightarrow$ Computer software appropriate for task and used within range of validity
(na) Use of resource outside range of established validity is justified
( ) Software runstreams correct and consistent with results
( ) Software output consistent with input
(4) Results consistent with applicable previous experimental or analytical findings
( $)$ Results and conclusions address all points and are consistent with task requirements and/or established limits or criteria
(4) Conclusions consistent with analytical results and established limits
(na) Uncertainty assessment appropriate and reasonable
(na) Other (define)

III. Comments:

IV. Reviener: Pay / hitinam 1-25-96 


\section{HEDOP REVIEH CHECKLIST \\ for \\ Radiological and Nonradiological Release Calculations}

Document Reviewed:

IRANSPORTATION SAFETY CLASS ANALYSIS FOR SHIPMENT OF SLUDGE FROM K EAST BASIN

Submitted by: J. V. Ne7son Date Submitted: January 18, 1996

Scope of Review: Entire Document

YES NO* N/A

W [ ] [ ] 1. A detailed technical review and approval of the environmental transport and dose calculation portion of the analysis has been performed and documented.

$[X][][1$

2. Detailed technical review(s) and approval(s) of scenario and release determinations have been performed and documented.

$X$ [ ] [ ] 3. HEDOP-approved code(s) were used.

[X] [ ] [ ] 4. Receptor locations were selected according to HEDOP recommendations.

DX] [ ] [ ]

5. All applicable environmental pathways and code options were

$\left[\begin{array}{lll}{[x} & {[} & {[}\end{array}\right]$ included and are appropriate for the calculations.

6. Kanford site data were used.

7. Model adjustments external to the computer program were justified and performed correctly.

$\left[\begin{array}{lll}{[} & {[} & {[}\end{array}\right]$

8. The analysis is consistent with HEDOP recommendations.

9. Supporting notes, calculations, comments, comment resolutions, or other information is attached. (Use the "Page 1 of $X "$ page numbering format and sign and date each added page.)

\& 1

10. Approval is granted on behalf of the Hanford Environmental Dose Overview Panel.

- All "NO" responses must be explained and use of nonstandard methods justified.

Reviewer Name: Paul D. Rittmann, B.A., M.S., Ph.D., C.H.P. (print or type)

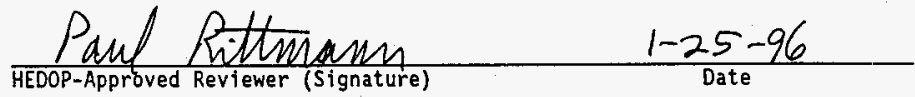


DISTRIBUTION SHEET

\begin{tabular}{|c|c|c|c|c|c|}
\hline \multirow{2}{*}{$\begin{array}{l}\text { To } \\
\text { Distribution }\end{array}$} & \multirow{2}{*}{\multicolumn{3}{|c|}{$\begin{array}{l}\text { From } \\
\text { Packaging Engineering }\end{array}$}} & \multicolumn{2}{|c|}{ Page 1 of 1} \\
\hline & & & & \multicolumn{2}{|c|}{ Date $05 / 01 / 96$} \\
\hline \multicolumn{4}{|l|}{ Project Title/Work Order } & \multicolumn{2}{|c|}{ EDT No. 615806} \\
\hline \multicolumn{4}{|c|}{$\begin{array}{l}\text { Packaging Design Criteria for the } K \text { East Basin Sludge } \\
\text { Transportation System (WHC-SD-TP-PDC-035) }\end{array}$} & \multicolumn{2}{|c|}{ ECN No. N/A } \\
\hline Name & MSIN & $\begin{array}{c}\text { Text } \\
\text { With All } \\
\text { Attach. }\end{array}$ & Text Only & $\begin{array}{l}\text { Attach./ } \\
\text { Appendix } \\
\text { Only }\end{array}$ & $\begin{array}{l}\text { EDT/ECN } \\
\text { Only }\end{array}$ \\
\hline $\begin{array}{l}\text { S. A. Brisbin } \\
\text { J. G. Field } \\
\text { J. E. Geary } \\
\text { J. R. Green } \\
\text { C. R. Hoover } \\
\text { D. W. McNa1ly } \\
\text { F. W. Moore } \\
\text { D. R. Precechtel } \\
\text { W. J. Schlauder } \\
\text { S. S. Shiraga } \\
\text { R. J. Smith } \\
\text { C. A. Thompson } \\
\text { T. A. Tomaszewski } \\
\text { Central Files } \\
\text { Doetment-Processing Center } \\
\text { WHC-SD-TP-PDC-031 File }\end{array}$ & 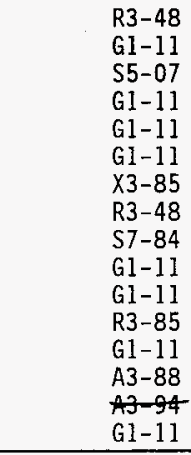 & 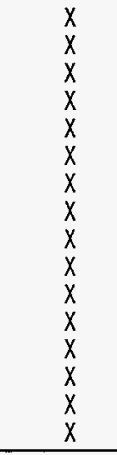 & & & \\
\hline
\end{tabular}

